Check for updates

Cite this: Mater. Adv., 2021,

2, 1760

\section{Methylene- and thioether-linked cyanobiphenyl- based liquid crystal dimers CBnSCB exhibiting room temperature twist-bend nematic phases and glasses $\uparrow$}

\author{
Yuki Arakawa, (D) * Kenta Komatsu, Takuma Shiba and Hideto Tsuji (D)
}

\begin{abstract}
The twist-bend nematic $\left(\mathrm{N}_{\mathrm{TB}}\right)$ phase is a new heliconical liquid crystal (LC) phase that is associated with spontaneous symmetry breaking for achiral bent LC molecules. Herein, we demonstrate a homologous series of LC dimers exhibiting the stable $N_{T B}$ phases, which undergo vitrification to give $N_{T B}$ glass $\left(N_{T B} G\right)$ phases upon cooling below room temperature. Methylene- and thioether-linked cyanobiphenyl-based LC dimer homologs, i.e., CBnSCB (carbon number of the central oligomethylene spacer, $n=2,4,6,8$, and 10, for a bent molecular geometry) were developed for the first time. The phase-transition behavior and phase characteristics of $\mathrm{CBnSCB}$ were investigated by polarized light optical microscopy (POM), differential scanning calorimetry (DSC), and X-ray diffractometry (XRD). All CBnSCB homologs were found to be mesogenic, wherein CBnSCB ( $n=4,6,8$, and 10) exhibited $\mathrm{N}_{\text {TB }}$ phases below the temperatures of conventional nematic $(N)$ phases. Additionally, CB2SCB, which possesses the shortest spacer, showed a kinetically induced, monotropic mesophase that was formed directly from the isotropic (I) phase with a strong first order phase-transition property. Although POM observations of CB2SCB revealed the presence of optical textures similar to modulated $\mathrm{N}$ or pseudo-layered $\mathrm{N}_{\text {TB }}$ phases, the XRD results indicated its apparently non-layered and liquid-like nature. In addition, the mesophase of CB2SCB was assumed to be miscible with the $\mathrm{N}_{T B}$ phase of CB4SCB. It was therefore suggested that $\mathrm{CB} 2 \mathrm{SCB}$ exhibited a $\mathrm{N}_{\mathrm{TB}}$ phase formed directly from the I phase. It is noteworthy that the $\mathrm{N}_{\mathrm{TB}}$ phases of $\mathrm{CBnSCB}$ ( $n=2,4,6$, and 8) underwent vitrification upon supercooling below room temperature, giving the $\mathrm{N}_{\mathrm{TB}} \mathrm{G}$ phases. In particular, $\mathrm{CBnSCB}$ ( $n=6$ and 8 ) exhibited remarkably stable $\mathrm{N}_{\mathrm{TB}}$ and $\mathrm{N}$ phases, undergoing no crystallization upon re-heating from the $\mathrm{N}_{\mathrm{TB}} \mathrm{G}$ phase up to the I phase. Furthermore, we investigated the phase-transition behaviors of previously reported analogs, i.e., bis(thioether)-linked CBSnSCB and ether- and thioether-linked CBOnSCB LC dimers (odd numbered $n=$ $3,5,7,9$, and 11, for a bent geometry) using POM, and observed $N_{T B}$ phase formation from the small supercooled $\mathrm{N}$ domains of $\mathrm{CBS11SCB}, \mathrm{CBO} 3 \mathrm{SCB}$, and $\mathrm{CBO} 11 \mathrm{SCB}$. It was therefore indicated that all reported bent CBSnSCB and CBOnSCB dimers $\left(n=3,5,7,9\right.$, and 11) form the $\mathrm{N}_{T B}$ phase. It was found that the $C B n S C B$ homologs exhibited remarkably stable $N_{T B}$ phases and vitrifiable tendencies compared with the previously reported $\mathrm{CBSnSCB}$ and $\mathrm{CBO} S \mathrm{SCB}$ analogs.
\end{abstract}

Received 17th December 2020 Accepted 14th February 2021

DOI: $10.1039 / \mathrm{d} 0 \mathrm{ma00990c}$

rsc.li/materials-advances
LC display technologies. Usually, molecules that produce thermotropic LCs are composed of rigid aromatic and aliphatic rings and flexible alkyl chains, which promote the microphase separation of each part to form mesophases.

In addition, the so-called LC dimers (or bimesogens), which are typically based on two rigid mesogenic structures linked by a flexible oligomethylene spacer, have also been actively researched. The molecular geometries of LC dimers are strongly influenced by the parity of the carbon or total atom numbers in the central spacers along the chains, giving a stretched Z-like (or an approximately linear) shape for even spacers, and a bent shape for odd spacers. ${ }^{1-5}$ This parity effect additionally bestows 
the LC dimers affluent mesomorphism ${ }^{6-9}$ and clear odd-even effects on physical properties. ${ }^{10,11}$

Furthermore, an emerging heliconical nematic (N) phase, the twist-bend nematic $\left(\mathrm{N}_{\mathrm{TB}}\right)$ phase, has offered a new insight into the diverse mesomorphism observed in LC dimers. Initially, the $\mathrm{N}_{\mathrm{TB}}$ phase was independently predicted by Meyer ${ }^{12}$ and Dozov, ${ }^{13}$ and was supported by a simulation by Memmer. ${ }^{14}$ Later, in-depth investigation of a few LC dimers including cyanobiphenyl (CB) dimers consisting of an odd carbon atom number on the oligomethylene spacer $(n)$, i.e., $\mathrm{CB} n \mathrm{CB}$, which exhibits a unknown nematic $\left(\mathrm{N}_{\mathrm{X}}\right)$ phase below the temperature of the conventional $\mathrm{N}$ phase, was conducted, ${ }^{15-18}$ and the $\mathrm{N}_{\mathrm{TB}}$ phase was identified with respect to the $\mathrm{N}_{\mathrm{X}}$ phase. ${ }^{15}$ In addition, several bent molecules exhibiting such $\mathrm{N}_{\mathrm{X}}$ phases, which are also reminiscent of $\mathrm{N}_{\text {TB }}$ phases, ${ }^{7,8,19-22}$ have been reported. Nevertheless, the detailed structures of the $\mathrm{N}_{\mathrm{TB}}$ phases are still under debate. $^{23-26}$

The representative features of the $\mathrm{N}_{\mathrm{TB}}$ phase include the spontaneous formation of right- and left-handed helical nanostructured domains formed by achiral molecules, and much shorter helical pitches of $\sim 10 \mathrm{~nm}^{27-32}$ compared with those of helicoidal chiral $\mathrm{N}\left(\mathrm{N}^{*}\right)$ or cholesteric $(\mathrm{Ch})$ phases, which usually have pitch ranges over hundreds of nanometers (see Fig. 1). In achiral molecular systems, both chiral domains are equivalently formed and are considered to be macroscopically achiral. In contrast, a macroscopic chirality was detected in the $\mathrm{N}_{\text {Tв }}$ phase of CB7CB by using circular dichroism spectroscopy. ${ }^{33}$ Scanning electron microscopy observations of the photocrosslinked samples of the $\mathrm{N}_{\mathrm{TB}}$ phase revealed a helical organization of the nanostructures. ${ }^{34-36}$ In addition to the $\mathrm{N}_{\mathrm{TB}}$ phase, other structurally associated mesophases, such as heliconical smectic (Sm) phases based on bent-core molecules ${ }^{37,38}$ and bent LC dimers, ${ }^{39,40}$ the twist grain-boundary-twist-bend nematic phase, ${ }^{41}$ and the splay-bend $\mathrm{N}\left(\mathrm{N}_{\mathrm{SB}}\right)$ phase electrically induced from the $\mathrm{N}_{\mathrm{TB}}$ phase $\mathrm{e}^{42-44}$ have been experimentally verified.

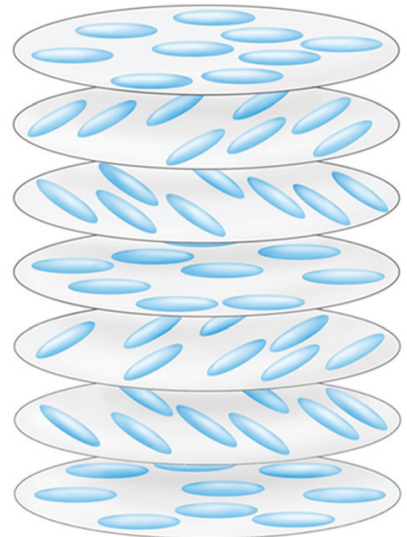

\section{Helicoidal chiral $\mathrm{N}$ phase (Ch phase)}

Fig. 1 Schematic models of the helicoidal chiral nematic $\left(N^{*}\right)$ or cholesteric (Ch) phase and the heliconical twist-bend nematic $\left(\mathrm{N}_{\mathrm{TB}}\right)$ phases. Reproduced from ref. 67 and 72 with permission.
Furthermore, the splay $\mathrm{N}\left(\mathrm{N}_{\mathrm{S}}\right)$ phase with the modulation rotated $90^{\circ}$ with respect to the $\mathrm{N}_{\mathrm{SB}}$ phase was discovered in some rod-like mesogens. ${ }^{45,46}$

The $\mathrm{N}_{\mathrm{TB}}$ phase is usually observed for bent LC dimers consisting of flexible spacers with an odd number of atoms. To date, a wide variety of bent LC dimers, ${ }^{47-72}$ oligomers, ${ }^{64,73-77}$ polymers, ${ }^{78}$ and bent-core molecules ${ }^{79,80}$ have been found to exhibit the $\mathrm{N}_{\mathrm{TB}}$ phase. In addition, $\mathrm{N}_{\mathrm{TB}}$ materials have been used for diverse applications such as photonic and optical devices,${ }^{81-84}$ gels $^{85}{ }^{8}$ elastic bodies, ${ }^{86}$ and photoalignment technologies. $^{87}$

For characterization and application purposes, it is necessary to develop materials that exhibit the $\mathrm{N}_{\mathrm{TB}}$ phase over a wide temperature range, the room-temperature $\mathrm{N}_{\mathrm{TB}}$ phase, and its glass (G) phase or $\mathrm{N}_{\mathrm{TB}}$ glass $\left(\mathrm{N}_{\mathrm{TB}} \mathrm{G}\right)$. Using mixtures with other mesogens is a useful method to lower the $\mathrm{N}-\mathrm{N}_{\mathrm{TB}}$ phasetransition temperature, ${ }^{18}$ ultimately achieving a metastable room temperature $\mathrm{N}_{\mathrm{TB}}$ phase ${ }^{88}$ and its photocrosslinked state. ${ }^{35}$ However, the formation of room-temperature $\mathrm{N}_{\mathrm{TB}}$ materials from their single-component systems indeed remains a rarity. ${ }^{50,61,64,67,68,70,72}$ This has restricted deep structural analyses and examination of the physical properties of the $\mathrm{N}_{\mathrm{TB}}$ phases, in addition to the development of new applications. Therefore, novel LC dimers that can maintain $\mathrm{N}_{\mathrm{TB}}$ phases at room temperature and produce the corresponding glasses are in high demand.

On the other hand, in our previous work, we revealed that thioether-linked LC dimers have a beneficial effect in the realization of the $\mathrm{N}_{\mathrm{TB}}$ phase over a wide temperature range and the room-temperature $\mathrm{N}_{\mathrm{TB}}$ and $\mathrm{N}_{\mathrm{TB}} \mathrm{G}$ phases. ${ }^{61,64,67,68,70}$ The asymmetrical methylene- and thioether-linked CB-based dimers bearing ethylene or hexamethylene spacers, namely CB2SCB and CB6SCB, respectively, was also reported previously. ${ }^{64}$ The latter exhibited an $\mathrm{N}_{\mathrm{TB}}$ phase, which gave the $\mathrm{N}_{\mathrm{TB}} \mathrm{G}$ phase upon supercooling to room temperature. However, its homologous series with other oligomethylene spacers has yet to be developed. Such systems are expected to be candidates for LC materials that exhibit room temperature $\mathrm{N}_{\mathrm{TB}}$ and $\mathrm{N}_{\mathrm{TB}} \mathrm{G}$ phases.

Herein we demonstrate LC dimer homologs that exhibit the room-temperature $\mathrm{N}_{\mathrm{TB}}$ and $\mathrm{N}_{\mathrm{TB}} \mathrm{G}$ phases. A homologous series of asymmetrically methylene- and thioether-linked CB-based LC dimers with oligomethylene spacers containing different numbers of carbon atoms $(n)$, i.e., $\mathrm{CB} n \mathrm{SCB}$, is established for the first time (Scheme 1). In this system, even numbers of carbon atoms were selected for the oligomethylene spacers, i.e., $n=2,4,6,8$, and 10 , to give odd total numbers of atoms in the spacer $n$ and the sulfur linkage (S) along the linear chain to ensure bent molecular geometries. In the present study, the previously reported $\mathrm{CB} n \mathrm{SCB}$ homologs $(n=2$ and 6) were also re-prepared and reinvestigated. The phase-transition behaviors, mesomorphism, and mesophase structures are evaluated using polarized light optical microscopy (POM), differential scanning calorimetry (DSC), and X-ray diffractometry (XRD). In addition, the phase-transition behaviors of the previously reported bent analogs, namely bis(thioether)-linked CBSnSCB and ether- and thioetherlinked CBOnSCB dimers $(n=3,5,7,9$, and 11, see Scheme 1), 


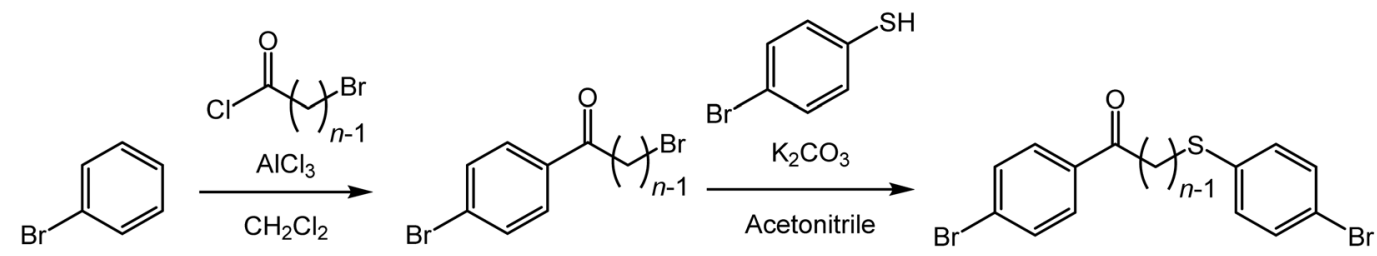

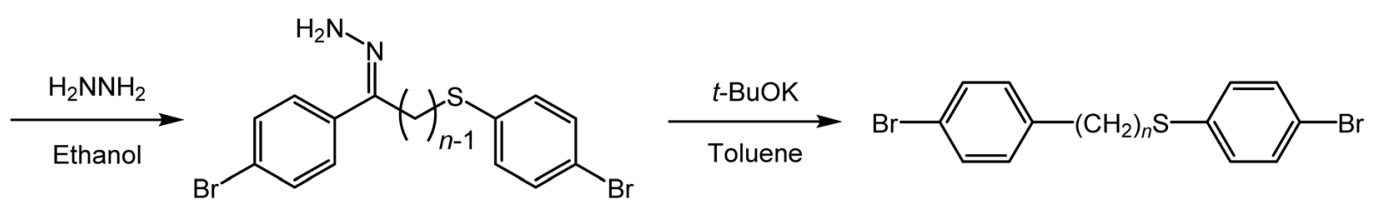

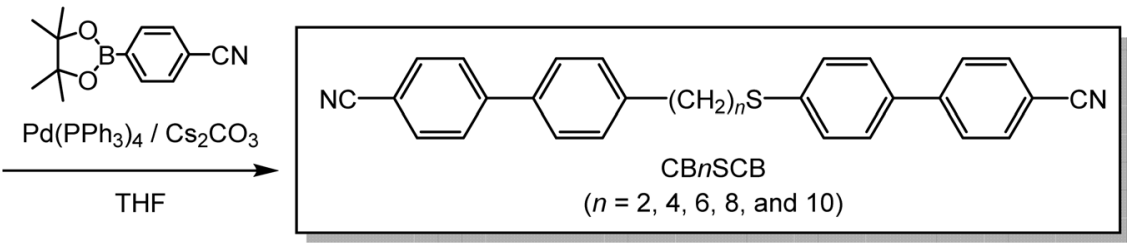<smiles>CC(C)Sc1ccc(-c2ccc(C#N)cc2)cc1</smiles>

$\mathrm{CBS} n S C B$

( $n=3,5,7,9$, and 11)<smiles>CC(C)Oc1ccc(-c2ccc(-c3ccc(C#N)cc3)cc2)cc1</smiles>

CBOnsCB

$(n=3,5,7,9$, and 11)

Scheme 1 Synthetic pathway to CBnSCB $(n=2,4,6,8$, and 10) and molecular structures of the previously reported CBSnSCB and CBOnSCB analogs ( $n=3,5,7,9$, and 11).

were also re-evaluated using POM. Moreover, the phase transitions of $\mathrm{CB} n \mathrm{SCB}, \mathrm{CBS} n \mathrm{SCB}$, and $\mathrm{CBO} n \mathrm{SCB}$ are comprehensively described.

\section{Experimental}

The $\mathrm{CB} n \mathrm{SCB}$ series was synthesized according to the route outlined in Scheme 1. The corresponding procedure for CB4SCB is described in the ESI. $\dagger$ The other homologs were synthesized by similar procedures, and their characterization data are also shown in the ESI. $\dagger$ The molecular structures were confirmed by ${ }^{1} \mathrm{H}$ and ${ }^{13} \mathrm{C}$ nuclear magnetic resonance (NMR) spectroscopy using JNM-ECS400 (400 MHz for ${ }^{1} \mathrm{H}$ and $100 \mathrm{MHz}$ for ${ }^{13} \mathrm{C}$ ) and JNM-ECX500 spectrometers (500 MHz for ${ }^{1} \mathrm{H}$ and $126 \mathrm{MHz}$ for ${ }^{13} \mathrm{C}$ ) (JEOL Ltd, Tokyo, Japan). Phase identification was carried out by POM observations using an Olympus polarized optical microscope (BX50, Tokyo, Japan) equipped with a Linkam temperature controller (LK-600PM, Surrey, UK). The phasetransition temperatures and the associated entropy changes $(\Delta S)$ were determined by DSC using a Shimadzu DSC 60 instrument at a heating and cooling rate of 3,10 , or $30{ }^{\circ} \mathrm{C} \min ^{-1}$ under

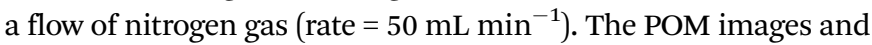
DSC curves of the dimers are shown either in the main text or in the ESI. $\dagger$ Powder XRD measurements for the mesophase and cold crystallization samples of CB2SCB were performed using a Rigaku Rint 2500 instrument with a $\mathrm{Cu} \mathrm{K} \alpha \mathrm{X}$-ray source. The mesophase and cold crystallization samples were prepared by rapidly cooling to $25{ }^{\circ} \mathrm{C}$ from the I phase at $140{ }^{\circ} \mathrm{C}$ and by heating from the mesophase at $25{ }^{\circ} \mathrm{C}$, respectively. The XRD measurements for both samples were conducted on a silicon substrate at $25{ }^{\circ} \mathrm{C}$. Temperature-variable XRD measurements for the crystal and mesophases of CB4SCB were conducted using a Bruker D8 DISCOVER diffractometer equipped with a Vantec-500 detector. $\mathrm{Cu} \mathrm{K} \alpha$ was used as the X-ray radiation source. CB4SCB powder was added and melted in a capillary glass tube of $1.5 \mathrm{~mm}$ diameter (WJM-Glass Müller $\mathrm{GmbH}$ ). The capillary specimen was sandwiched between permanent magnets $(B=300 \mathrm{mT})$ in a folder. The capillary samples were set on a Bruker TCPU-P stage to control the sample temperature during X-ray irradiation. Following heating of the specimen to the isotropic (I) phase to remove its thermal history, the measurements were carried out at different mesophase temperatures. Binary mixtures of the $\mathrm{CB} n$ SCB homologs ( $n=2$ and 4 ) were prepared according to the literature. ${ }^{89}$ After dissolving the weighed dimers in dichloromethane to obtain a solution with a concentration of $10 \mathrm{mg} \mathrm{mL} \mathrm{m}^{-1}$, the solvent was slowly evaporated under reduced pressure. The mixed samples, which had been dried sufficiently under reduced pressure, were heated to $150{ }^{\circ} \mathrm{C}$ (to give the I phase), and then cooled to ambient temperature to produce homogeneous mixtures. 
Subsequently, the phase transitions of the mixtures upon cooling from the I phases were investigated by POM at a cooling rate of $3{ }^{\circ} \mathrm{C} \min ^{-1}$.

\section{Results and discussion}

The thermal phase sequences and the phase-transition temperatures at the crystal $(\mathrm{Cr})$ phase to the $\mathrm{N}$ or I phases (melting points, $T_{\mathrm{m}}$ ) and the $\mathrm{N}$ to I phases upon first heating, and at the I to $\mathrm{N}$ phases $\left(T_{\mathrm{IN}}\right)$, the $\mathrm{N}$ to $\mathrm{N}_{\mathrm{TB}}$ phases $\left(T_{\mathrm{NNTB}}\right)$, the glass transition $\left(T_{\mathrm{g}}\right)$, and the crystallization $\left(T_{\mathrm{Cr}}\right)$ upon cooling of $\mathrm{CB} n \mathrm{SCB}$ are tabulated in Table 1 . In addition, the phase diagram of $\mathrm{CB} n \mathrm{SCB}$ as a function of $n$ is shown in Fig. 2. Initially, we discuss the results mainly for $\mathrm{CB} n \mathrm{SCB}(n=4,6,8$, and 10), and then move on to discuss the phase characterization of the shortest CB2SCB.

Upon first heating, $\mathrm{CB} n \mathrm{SCB}(n=6,8$, and 10) exhibited an $\mathrm{N}$ phase, whereas CBnSCB ( $n=2$ and 4 ) showed only one $T_{\mathrm{m}}$ peak corresponding to the $\mathrm{Cr}$ to I phase transition (Fig. S1-S5 in the ESI $\dagger$ ). It is clear that a relatively long spacer is a prerequisite to form the $\mathrm{N}$ phase. This trend could be associated with molecular geometrical biaxiality and anisotropy, which is enhanced for LC dimers with short and long spacers, respectively. In other words, in comparison with short $\mathrm{CB} n \mathrm{SCB}(n=2$ and 4$)$ exhibiting a more bent or biaxial geometry, intermediate and long CBnSCB dimers $(n=6,8$, and 10$)$ with a more anisotropic geometry are advantageous in that they form LC phases upon heating.

Upon cooling, $\mathrm{CB} n \mathrm{SCB}(n=4,6,8$, and 10$)$ clearly exhibited the $\mathrm{N}_{\mathrm{TB}}$ phases below the $\mathrm{N}$ phases, which follows the usual thermal phase sequence of $\mathrm{N}_{\mathrm{TB}}-\mathrm{N}-\mathrm{I}$; this is not the case for CB2SCB, as discussed later. Phase identification was achieved by POM observations and XRD measurements. In the nontreated glass cells, the marble and schlieren $\mathrm{N}$ textures of CBnSCB $(n=4,6,8$, and 10) transformed into blocky, focal conic, polygonal, and striped textures below the $\mathrm{N}$ phases [Fig. 3 and Fig. S6, S7, ESI $\dagger$ ]. Such optical textures are typical of the pseudo-layered $\mathrm{N}_{\text {TB }}$ phase. In addition, the POM images of CB4SCB and CB8SCB obtained using a uniaxially rubbed polyimide-surface cell for planar alignment displayed a striped texture below the $\mathrm{N}$ phase [Fig. 3(c) and (d), respectively], which
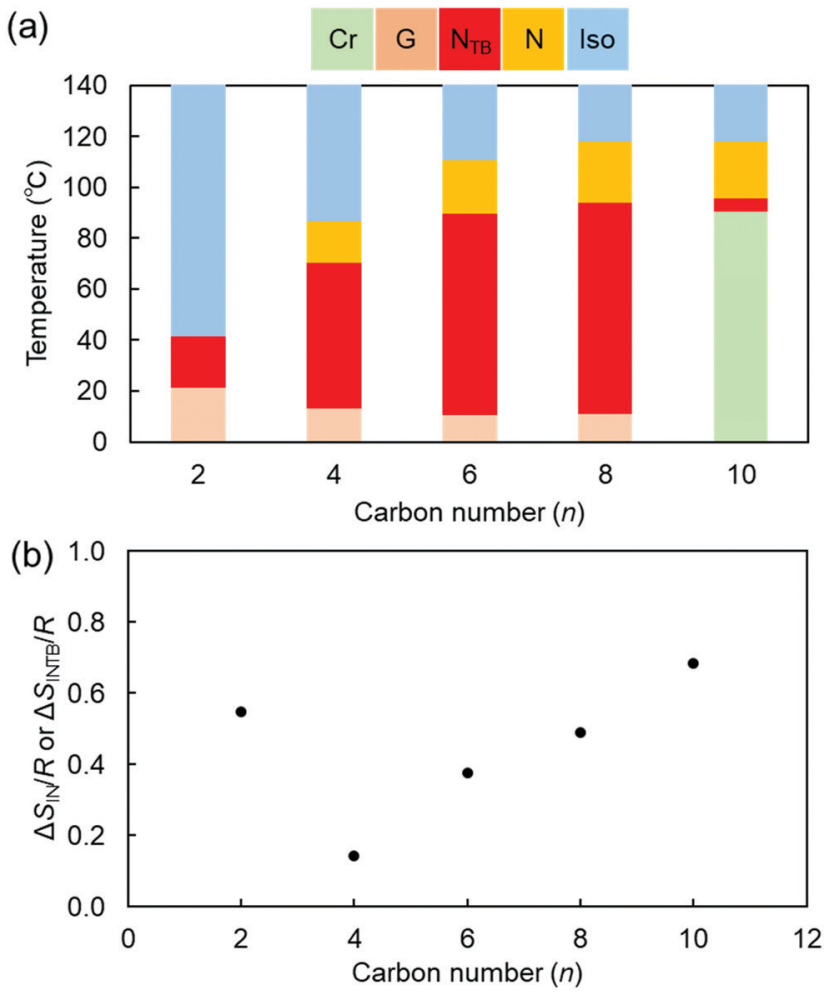

Fig. 2 (a) Phase diagram and (b) $\Delta S_{\mathrm{IN}} / R$ (or $\Delta S_{\mathrm{INTB}} / R$ for $\mathrm{CB} 2 \mathrm{SCB}$ ) as a function of $n$ upon the cooling of CBnSCB.

was similar to that previously reported for $\mathrm{CB} 6 \mathrm{SCB},{ }^{64}$ further supporting evidence of the $\mathrm{N}_{\mathrm{TB}}$ phase. This striped texture is assumed to arise from the undulation of the pseudo layers based on the Helfrich-Hurault buckling instability. ${ }^{28,36}$ The helical axes and pseudo layers orient parallel and perpendicular to the rubbing (or stripe) direction, respectively. As shown in the magnified image of CB8SCB in the inset of Fig. 3(d), the diagonal line textures represented by zig-zag black solid lines in each stripe are oriented in the same direction in alternate stripes.

Temperature-variable XRD measurements for the $\mathrm{N}$ and $\mathrm{N}_{\mathrm{TB}}$ phases of CB4SCB were also conducted, for which the obtained one-dimensional (1D) XRD profiles are shown in Fig. S8 (ESI $\dagger$ ).

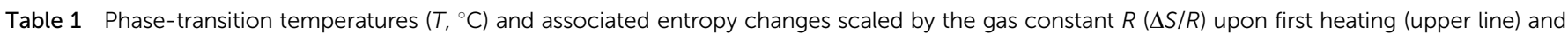
cooling (bottom line) at a rate of $10{ }^{\circ} \mathrm{C} \mathrm{min}-1$ of $\mathrm{CBnSCB}$

\begin{tabular}{|c|c|c|c|c|c|c|c|c|c|c|c|}
\hline Code & $n$ & Phase & $T\left({ }^{\circ} \mathrm{C}\right)$ & $\Delta S / R$ & Phase & $T\left({ }^{\circ} \mathrm{C}\right)$ & $\Delta S / R$ & Phase & $T\left({ }^{\circ} \mathrm{C}\right)$ & $\Delta S / R$ & Phase \\
\hline \multirow[t]{10}{*}{$\mathrm{CB} n \mathrm{SCB}$} & $2^{a}$ & $\mathrm{Cr}$ & 131.0 & 7.2 & & & & & & & I \\
\hline & & $\mathrm{Cr}$ & & & $\mathrm{N}_{\mathrm{TB}}$ & 42.5 & $0.55^{b}$ & & & & I \\
\hline & 4 & $\mathrm{Cr}$ & 126.2 & 7.9 & & & & & & & I \\
\hline & & $\mathrm{G}$ & 13.1 & & $\mathrm{~N}_{\mathrm{TB}}$ & 70.3 & 0.23 & $\mathrm{~N}$ & 86.8 & 0.14 & I \\
\hline & $6^{a}$ & $\mathrm{Cr}$ & 99.0 & 10.3 & & & & $\mathrm{~N}$ & 113.2 & 0.34 & I \\
\hline & & $\mathrm{G}$ & 10.4 & & $\mathrm{~N}_{\mathrm{TB}}$ & 89.6 & 0.25 & $\mathrm{~N}$ & 110.7 & 0.37 & I \\
\hline & 8 & $\mathrm{Cr}$ & 92.6 & 12.4 & & & & $\mathrm{~N}$ & 119.8 & 0.48 & I \\
\hline & & $\mathrm{G}$ & 10.9 & & $\mathrm{~N}_{\mathrm{TB}}$ & 93.9 & & $\mathrm{~N}$ & 117.8 & 0.49 & I \\
\hline & 10 & $\mathrm{Cr}$ & 103.4 & 12.1 & & & & $\mathrm{~N}$ & 119.0 & 0.69 & I \\
\hline & & $\mathrm{Cr}$ & 86.5 & 11.4 & $\mathrm{~N}_{\mathrm{TB}}$ & 95.5 & & $\mathrm{~N}$ & 117.8 & 0.69 & I \\
\hline
\end{tabular}

${ }^{a}$ Re-evaluated in the present study. ${ }^{b}$ The $\Delta S / R$ value is taken at a rate of $30{ }^{\circ} \mathrm{C}$ min ${ }^{-1}$ to prevent crystallization. 

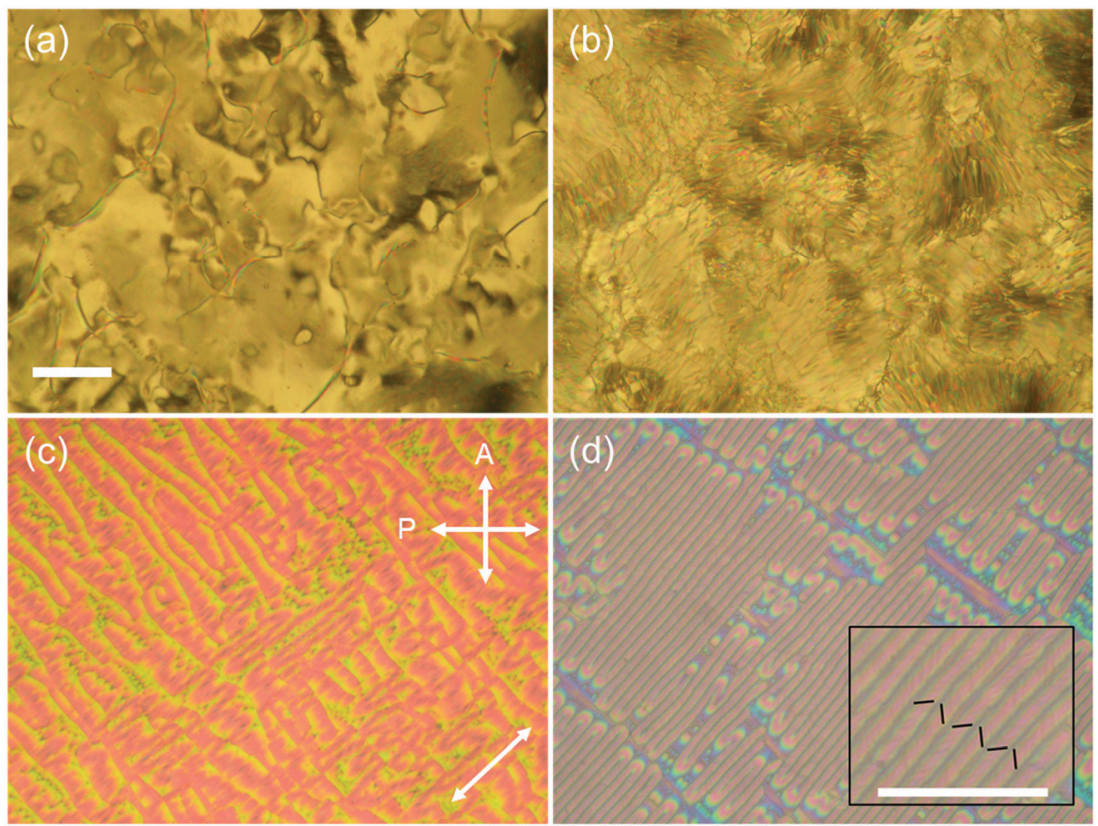

(d)

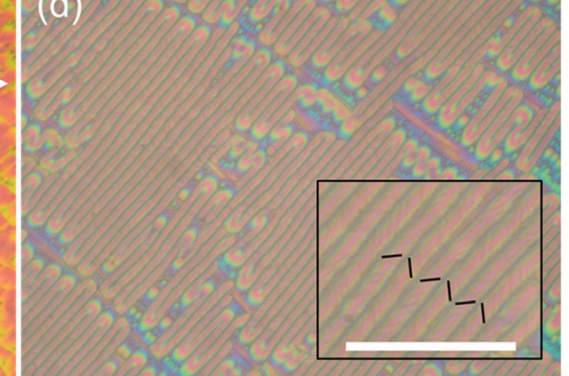

Fig. 3 POM images of (a) the $\mathrm{N}$ phase at $75{ }^{\circ} \mathrm{C}$ and (b) the $\mathrm{N}_{\mathrm{TB}}$ phase at $70{ }^{\circ} \mathrm{C}$ in non-treated glass of $\mathrm{CB} 4 \mathrm{SCB}$, and the $\mathrm{N}_{\mathrm{TB}}$ phases of (c) $\mathrm{CB} 4 \mathrm{SCB}$ at $55{ }^{\circ} \mathrm{C}$ and (d) of $\mathrm{CB} 8 \mathrm{SCB}$ at $70^{\circ} \mathrm{C}$ in uniaxially rubbed polyimide-surface planar alignment cells with a thickness of $5 \mu \mathrm{m}$. The white scale bars in panel (a) and in the inset of panel (d) correspond to $50 \mu \mathrm{m}$. The white diagonal double-headed arrow in panel (c) represents the rubbing direction in the samples displayed in panels (c) and (d). The inset of panel (d) shows a magnification of the image given in panel (d).

It was found that the XRD profiles in the $\mathrm{N}_{\mathrm{TB}}$ phase of $\mathrm{CB} 4 \mathrm{SCB}$ at $30{ }^{\circ} \mathrm{C}$ did not show any peaks in the small-angle region, and were similar to those of the $\mathrm{N}$ phase at $85{ }^{\circ} \mathrm{C}$. The observed broad wide-angle diffraction $\left(2 \theta=20.8^{\circ}\right.$, which corresponds to $d$-spacing $=4.27 \AA$ ) in the $\mathrm{N}_{\mathrm{TB}}$ phase at $30^{\circ} \mathrm{C}$ suggests their fluid liquid-like correlation to the molecular transverse direction. The XRD results therefore support the $\mathrm{N}_{\mathrm{TB}}$ phase, and indicate that the Sm-like optical textures based on POM could be attributable to the presence of pseudo-layered structures rather than unambiguous layered Sm phases. In addition to the observed POM textures, the fact that the 1D-XRD profile of the $\mathrm{N}_{\mathrm{TB}}$ phase at $30{ }^{\circ} \mathrm{C}$ does not contain any discernible crystallization peaks confirms that the $\mathrm{N}_{\mathrm{TB}}$ phase stably cooled to room temperature without crystallization, to provide the $\mathrm{N}_{\mathrm{TB}} \mathrm{G}$ phase. When the sample was allowed to stand for 1 week, the XRD pattern displayed several crystalline peaks. The $d$-spacing of a main small-angle peak at $2 \theta=7.32^{\circ}$ corresponded to $12.1 \AA$, which is approximately half of the molecular length, indicating the so-called intercalated structures of the dimers. Furthermore, a very minor small-angle peak was observed at $2 \theta=3.69^{\circ}$, and its $d$-spacing was $23.9 \AA$, which is close to the full molecular length.

The DSC curves of second heating and first cooling of $\mathrm{CB} n \mathrm{SCB}(n=2,4,6$, and 8$)$ are shown in Fig. 4. Interestingly, the $\mathrm{N}_{\mathrm{TB}}$ phases of $\mathrm{CB} n \mathrm{SCB}(n=4,6$, and 8) were supercooled to room temperature without any discernible crystallization peaks, and these samples vitrified to yield the $\mathrm{N}_{\mathrm{TB}} \mathrm{G}$ phase upon cooling [Fig. 4(b)-(d)]. The mesophase of CB2SB was also vitrified upon cooling to room temperature [Fig. 4(a)]. In the present study, DSC measurements were re-performed for $\mathrm{CB} n \mathrm{SCB}(n=2$ and 6 ), and compared with those reported in our previous report. ${ }^{64}$ The present batch of CB6SCB did not show any crystallization upon cooling to $0{ }^{\circ} \mathrm{C}$. This is different from the results for the previous batch, which exhibited crystallization upon cooling and subsequent heating. The $\mathrm{N}_{\text {Тв }}$ phase of CB10SCB underwent crystallization upon cooling [Fig. S5, ESI†]. The mesophases of CB4SCB were crystallized under similar second heating courses, as shown in Fig. 4(b). However, it is noteworthy that upon second heating from the $\mathrm{N}_{\mathrm{TB}} \mathrm{G}$ phase at $0{ }^{\circ} \mathrm{C}$ after cooling from the I phase, the $\mathrm{N}_{\mathrm{TB}}$ and $\mathrm{N}$ phases of $\mathrm{CB} n \mathrm{SCB}$ ( $n=6$ and 8 ) did not undergo cold crystallization, retaining the mesophases up to the I phase transition [Fig. 4(c) and (d)]. Such a prominent $\mathrm{N}_{\mathrm{TB}}$ and $\mathrm{N}$ phase stability observed for $\mathrm{CB} n \mathrm{SCB}(n=6$ and 8$)$ is similar to that of thioether-linked naphthalene-based LC dimers, which were reported in our previous work. ${ }^{67}$ In addition, to verify the stability of the $\mathrm{N}_{\mathrm{TB}}$ and $\mathrm{N}_{\mathrm{TB}} \mathrm{G}$ phases of $\mathrm{CB} n \mathrm{SCB}(n=4,6$, and 8), their DSC samples were rapidly cooled from their I phases to their corresponding $\mathrm{N}_{\mathrm{TB}} \mathrm{G}$ phases, and allowed to stand at room temperature for $3 \mathrm{~d}$. Subsequently, they were re-evaluated upon heating from $0{ }^{\circ} \mathrm{C}$ to the temperatures of their I phases. As can be seen in Fig. S2-S4 (ESI $\dagger$ ), the obtained DSC curves of $\mathrm{CB} n \mathrm{SCB}$ ( $n=4$ and 6) revealed that glass transition and cold crystallization took place from the LC phases $\left(\mathrm{N}_{\mathrm{TB}}\right.$ or $\left.\mathrm{N}\right)$ to the $\mathrm{Cr}$ phases, indicating that the $\mathrm{N}_{\mathrm{TB}}$ or $\mathrm{N}_{\mathrm{TB}} \mathrm{G}$ phases could be maintained for $3 \mathrm{~d}$. To our surprise, CB8SCB exhibited no discernible cold crystallization peak, but did undergo an $\mathrm{N}_{\mathrm{TB}}-\mathrm{N}$ phase transition at $95.8{ }^{\circ} \mathrm{C}$ and an $\mathrm{N}-\mathrm{I}$ phase transition at $119.3{ }^{\circ} \mathrm{C}$ with a small enthalpy change of $1.69 \mathrm{~kJ} \mathrm{~mol}^{-1}$, highlighting the prominent stability of the $\mathrm{N}_{\mathrm{TB}}$ and/or $\mathrm{N}_{\mathrm{TB}} \mathrm{G}$ phases of CB8SCB.

It is known that the $\mathrm{N}-\mathrm{N}_{\mathrm{TB}}$ phase transition depends on the DSC scanning rate, and the phase-transition behavior gradually 

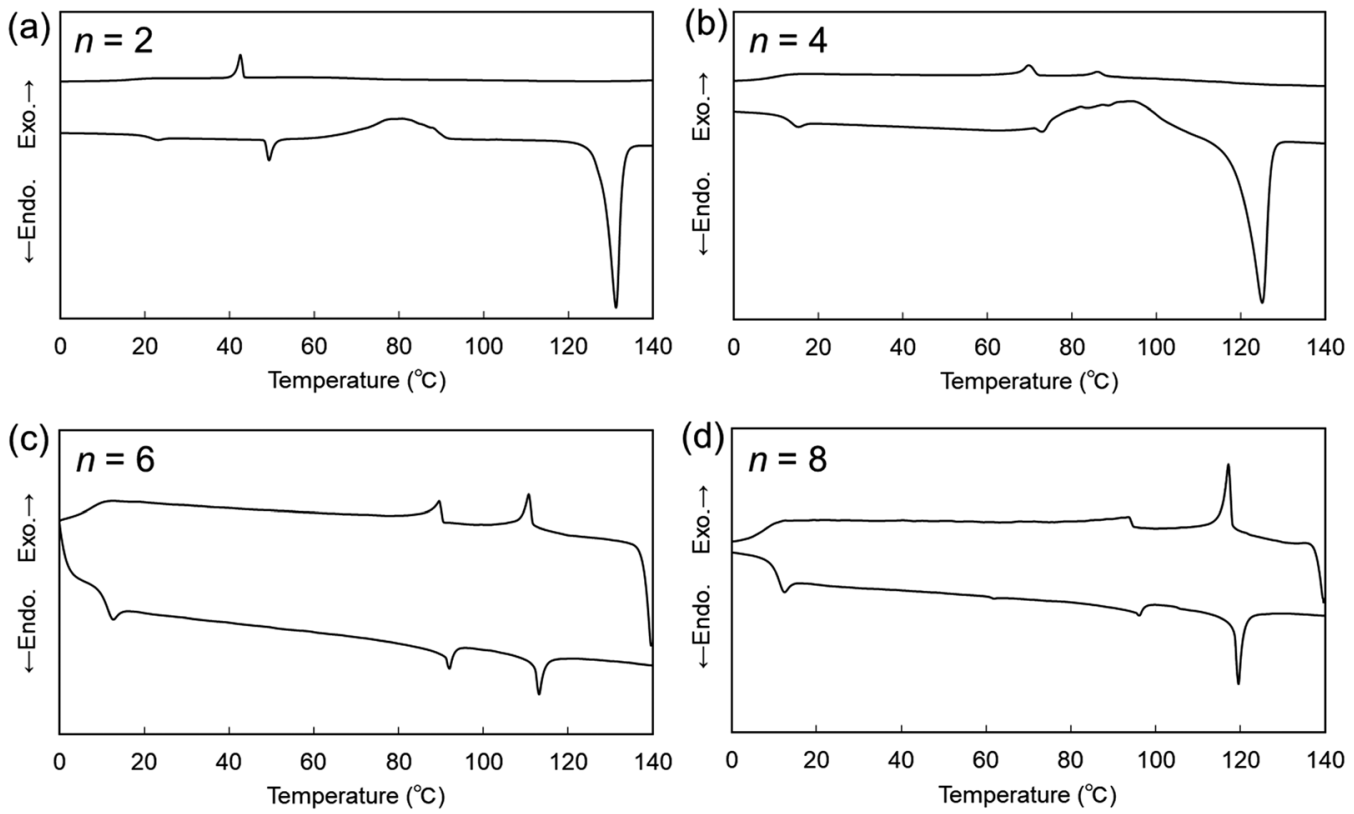

Fig. 4 DSC curves of (a) CB2SCB (b) CB4SCB, (c) CB6SCB, and (d) CB8SCB upon second heating and first cooling at a rate of $10{ }^{\circ} \mathrm{C} \mathrm{min}{ }^{-1}$.

changes from first-order-like to second-order-like upon increasing the rate. For example, at a relatively high rate, such as the $10{ }^{\circ} \mathrm{C} \mathrm{min}^{-1}$ used in the present study, second-order-like transitions were observed in the LC dimers. ${ }^{61,67,68,70,71,92}$ In addition, in a few cases of the LC dimers homologs, it was reported that the DSC peak on the $\mathrm{N}-\mathrm{N}_{\mathrm{TB}}$ phase transition alters from second-order-like to first-order-like with decreasing the spacer chain length, ${ }^{57,61,70,71}$ which could be associated with a larger structural difference between the $\mathrm{N}$ and $\mathrm{N}_{\text {Тв }}$ phases for shorter spacer homologs than for the longer counterparts, implying the molecular rigidity and packing manner in the $\mathrm{N}_{\text {тв }}$ phases for shorter spacer LC dimers. ${ }^{70}$ In the present study, the $\mathrm{N}-\mathrm{N}_{\mathrm{TB}}$ transitions of $\mathrm{CB} n \mathrm{SCB}$ gradually transformed from secondorder-like to first-order-like peak shapes with decreasing values of $n$ (from 10 to 4), as shown in (Fig. 4 and Fig. S5, ESI †). It is noteworthy that $\mathrm{CB} n \mathrm{SCB}$ ( $n=4$ and 6 ) exhibited first-order-like peaks with $\Delta S_{\mathrm{NNTB}} / R$ values of 0.23 and 0.25 , respectively, even though the DSC scanning rate was $10{ }^{\circ} \mathrm{C} \mathrm{min}^{-1}$. In particular, the $\Delta S_{\mathrm{NNTB}} / R$ of 0.23 for $\mathrm{CB} 4 \mathrm{SCB}$ is larger than the corresponding $\Delta S_{\mathrm{IN}} / R$, i.e., 0.14 . Such phase transitions also indicate the largely different structures between the $\mathrm{N}$ and $\mathrm{N}_{\mathrm{TB}}$ phases (especially in the presence of unique characteristics in the $\mathrm{N}_{\mathrm{TB}}$ phase). ${ }^{70}$ These results may imply that this trend could eventually lead to a strong first order property with a $\Delta S / R$ of 0.55 on the phase-transition peak from the I phase to the mesophase of CB2SCB, as discussed later. As shown in Fig. 2(b), the $\Delta S_{\mathrm{IN}} / R$ value decreases with decreasing $n$ (from 10 to 4 ). This behavior is associated with the enhanced bent or biaxial molecular geometries resulting from reduced spacer lengths.

We then moved on to examine the phase behavior and characterization of the shortest CB2SCB homolog. CB2SCB shows unique phase-transition behavior depending on the thermal treatment conditions outlined in our previous study. ${ }^{64}$ The DSC curves of CB2SCB upon first heating and cooling are shown in Fig. S1 (ESI $\dagger$ ) and Fig. 5, respectively. It can be seen that CB2SCB exhibited one $T_{\mathrm{m}}$ at $\sim 131{ }^{\circ} \mathrm{C}$, which corresponded to the $\mathrm{Cr}-\mathrm{I}$ phase transition upon the first heating of the pristine solutioncrystallized sample (Fig. S1, ESI $\dagger$ ). ${ }^{64}$ Upon cooling at a high rate, i.e., 10 or $30^{\circ} \mathrm{C} \mathrm{min}^{-1}$, the exothermic peak at $\sim 43{ }^{\circ} \mathrm{C}$ with a first order transition property was observed by DSC [Fig. 4(a) and 5]. On the other hand, at a low cooling rate (i.e., $\left.3^{\circ} \mathrm{C} \mathrm{min}^{-1}\right)$, a broadened crystallization peak was also observed between $\sim 85$ and $50{ }^{\circ} \mathrm{C}$ (Fig. 5). In this study, we further reinvestigated the phasetransition behavior of $\mathrm{CB} 2 \mathrm{SCB}$ and found that the former peak at $\sim 43{ }^{\circ} \mathrm{C}$ corresponds to a transition from the I phase to a kind of mesophase that was not the $\mathrm{Cr}$ phase; thus, CB2SCB is mesogenic. This phase, which was observed as a turbid liquid, was a highly viscous, which was confirmed by pressing and sliding.

POM observations of CB2SCB revealed birefringent domains gradually growing in a dark texture of the I phase [Fig. 6(a)]

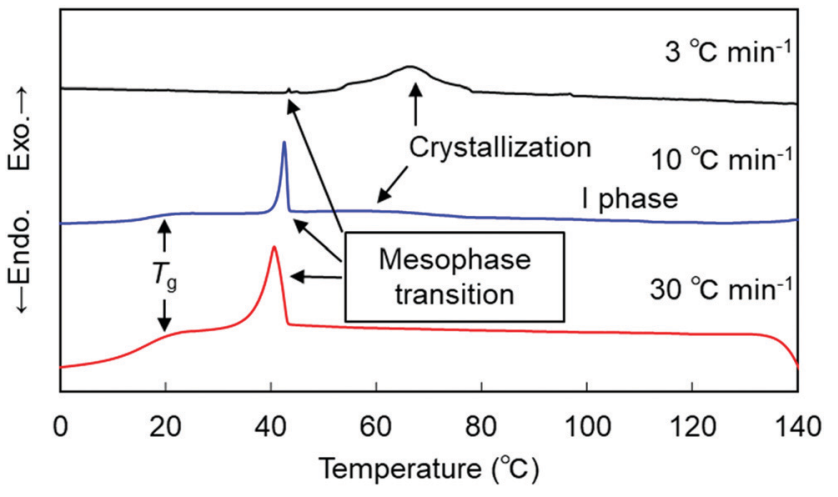

Fig. 5 DSC curves of CB2SCB upon cooling at different rates, which were re-evaluated in the present study. 

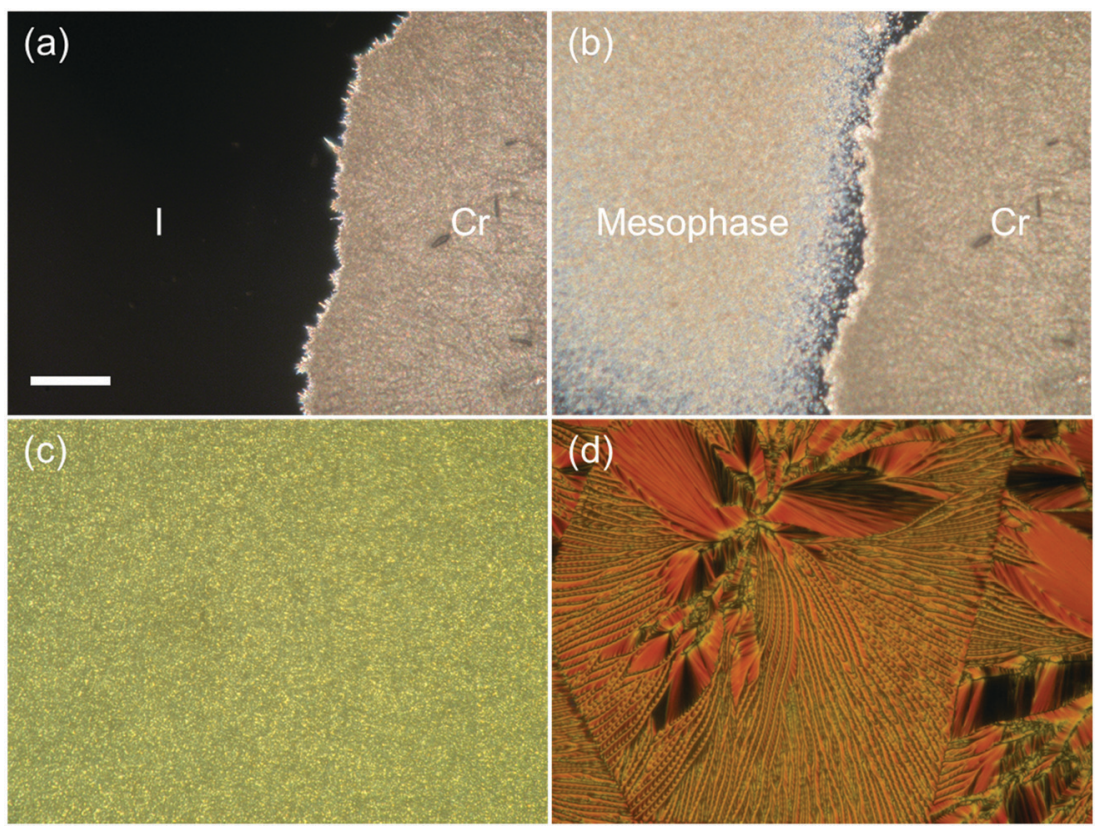

Fig. 6 Polarized light optical microscopy (POM) images of $\mathrm{CB} 2 \mathrm{SCB}$ in a non-treated glass cell: (a) the I and $\mathrm{Cr}$ phases at $47{ }^{\circ} \mathrm{C}$, (b) the mesophase [transitioned from the I phase of panel (a)] and the $\mathrm{Cr}$ phase at $45^{\circ} \mathrm{C}$ upon cooling at a rate of $3{ }^{\circ} \mathrm{C} \mathrm{min}{ }^{-1}$. (c) The mesophase at $32{ }^{\circ} \mathrm{C}$ upon cooling at a rate of $10{ }^{\circ} \mathrm{C} \mathrm{min}{ }^{-1}$, and (d) upon holding at a temperature in the vicinity of the I-to-mesophase phase transition after cooling to $\sim 50{ }^{\circ} \mathrm{C}$ at a fast cooling rate over $30^{\circ} \mathrm{C} \mathrm{min}^{-1}$. The white scale bar in panel (a) corresponds to $50 \mu \mathrm{m}$.

upon cooling at a relatively low rate of $3{ }^{\circ} \mathrm{C} \mathrm{min}{ }^{-1}$ from the high temperature I phase over $100{ }^{\circ} \mathrm{C}$, which were attributed to partial crystallization and corresponded to the abovementioned broadening peak at $\sim 85-50{ }^{\circ} \mathrm{C}$ in the DSC curve (Fig. 5). During the slow growth of these partial Cr domains, the remaining I phase domain (or dark region) transitioned to the mesophase at $\sim 43{ }^{\circ} \mathrm{C}$ [Fig. 6(b)]. Fig. 6(c) shows the birefringent texture that emerged at $\sim 43{ }^{\circ} \mathrm{C}$ during cooling from the I phase at a rate of $10^{\circ} \mathrm{C} \mathrm{min}^{-1}$. However, the individual domain observed in the optical texture by POM is particularly small due to its highly viscoelastic nature, which does not allow us to identify the type of mesophase. However, it is interesting to note that during holding at temperature in the vicinity of the I-to-mesophase phase transition after cooling to $50{ }^{\circ} \mathrm{C}$ at a high cooling rate over $30^{\circ} \mathrm{C} \mathrm{min}^{-1}$ to kinetically prevent the gradual crystallization at $\sim 85-50{ }^{\circ} \mathrm{C}$ in the I phase, discernible ropelike or striped, fan-shaped-like, and polygonal-like textures were gradually formed from circular domains [Fig. 6(d)]. This result is reminiscent of the presence of a modulated $\mathrm{N}$ phase and similar to the pseudo layered $\mathrm{N}_{\mathrm{TB}}$ phase. Although we attempted to observe the mesophase of CB2SCB via POM using a uniaxially rubbed polyimide-surface glass cell for planar alignment, only the small-domain optical texture similar to that seen in Fig. 6(c) was observed, and the alignment could not be achieved.

Subsequently, we employed POM to examine the miscibility of CB2SCB blended with CB4SCB as a reference sample for their contact preparation and binary mixtures. The CB4SCB analog forms the $\mathrm{N}_{\mathrm{Tв}}$ phase and is structurally similar to CB2SCB; therefore, it is assumed that the possibility of their phase separation being attributed to a difference in molecular structures is prevented. The POM images of their contact preparation are shown in Fig. 7. As shown in Fig. $7(\mathrm{a})$, the $\mathrm{N}$ phase texture (bottom left) and the I phase region (top right) correspond to the CB4SCB-rich region and the CB2SCB-rich region, respectively. The $\mathrm{N}$ phase texture in the CB4SCB-rich region transformed to the blocky texture of the $\mathrm{N}_{\mathrm{TB}}$ phase [Fig. 7(b)]. In the intermediate regions between the CB4SCB-rich and CB2SCB-rich regions in Fig. 7(b)-(e), the $\mathrm{N}$ phase texture gradually formed from the CB4SCB-rich to the CB2SCB-rich regions, and subsequently, the $\mathrm{N}$ phase gradationally transitioned to the $\mathrm{N}_{\mathrm{TB}}$ phase, ultimately resulting in the appearance of an ambiguous texture in the CB2SCB-rich region, similar to the mesophase of CB2SCB, as shown in Fig. 7(e) and (f). These gradual changes in the POM textures could be ascribed to the concentration gradient between CB4SCB and CB2SCB. It is interesting to note that the unclear optical texture similar to that of the mesophase of CB2SCB continuously emerged from the $\mathrm{N}$ or $\mathrm{N}_{\mathrm{TB}}$ borders in the intermediate regions and at higher temperatures than $\sim 43{ }^{\circ} \mathrm{C}$ of the I-to-mesophase phasetransition temperature of CB2SCB. Subsequently, the binary mixtures of CB2SCB blended with CB4SCB were investigated. The phase diagram of the binary mixture upon cooling as a function of the molar fraction of CB4SCB was determined by POM observations and is illustrated in Fig. 8(a) along with the representative optical textures [Fig. 8(b)-(e)]. Both molecules were miscible in one another without phase separation. Surprisingly, the binary mixtures containing a low mol\% of CB4SCB (or a high $\mathrm{mol} \%$ of $\mathrm{CB} 2 \mathrm{SCB}$ ) exhibited direct $\mathrm{N}_{\mathrm{TB}}$ phase formation from the I phase at temperatures higher than that of the I-to-mesophase phase transition of CBS2CB $\left(\sim 43{ }^{\circ} \mathrm{C}\right)$. Fig. $8(\mathrm{~b})$ and (c) show the 


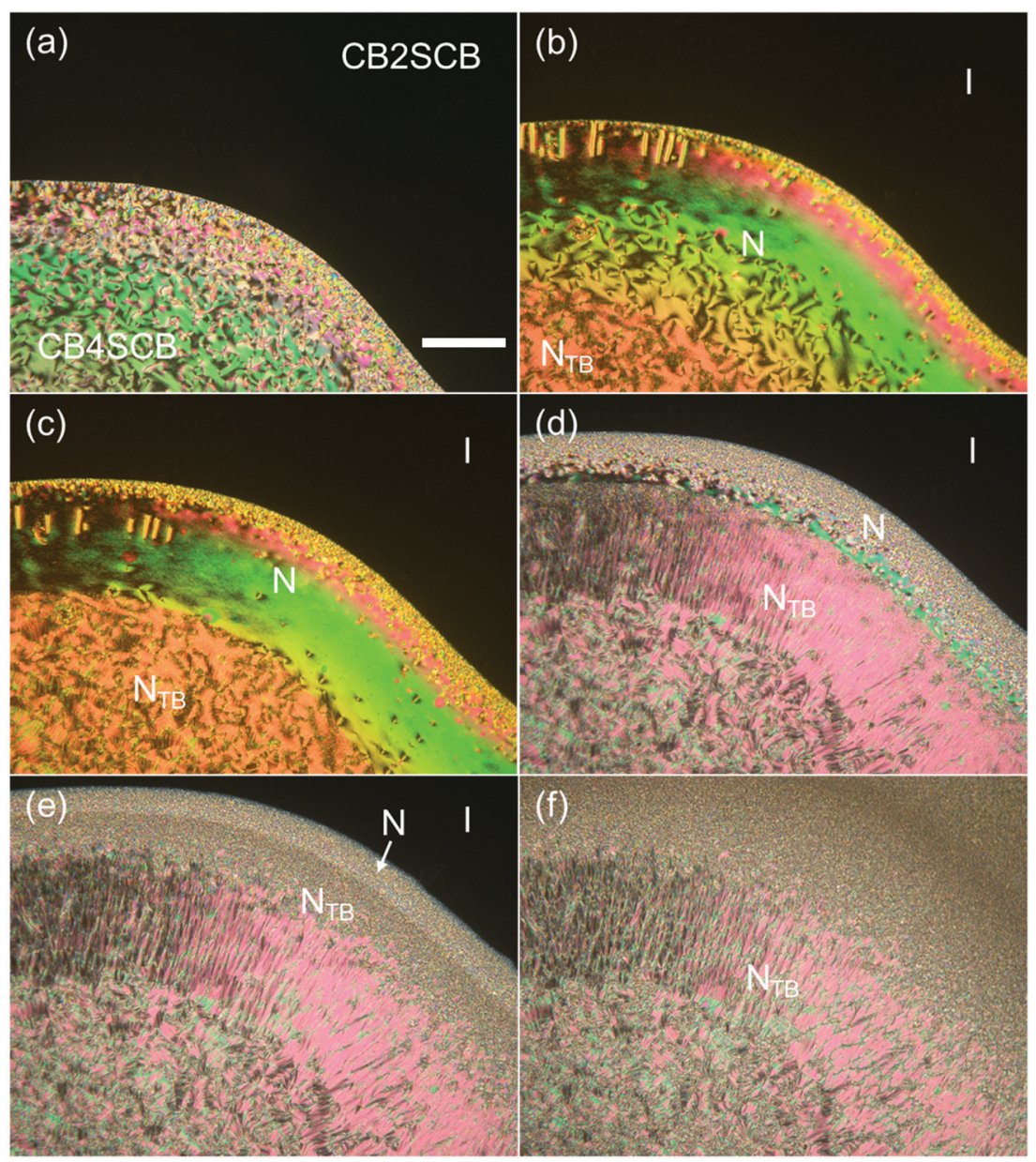

Fig. 7 POM images of the contact preparation of $C B 2 S C B$ and $C B 4 S C B$ in a non-treated glass cell: (a) the I phase of the CB2SCB-rich region (top right) and the $N$ phase of the $C B 4 S C B$-rich region (bottom left) at $75^{\circ} \mathrm{C}$, and (b)- $(f)$ the gradational changes in optical textures from the $N_{T B}$ phase of $C B 4 S C B-$ rich to the CB2SCB-rich regions at (b) 70 , (c) 67 , (d) 61 , (e) 58 , and (f) $48{ }^{\circ} \mathrm{C}$, respectively. The white scale bar in panel (a) corresponds to $100 \mu \mathrm{m}$.

blocky texture typical of the $\mathrm{N}_{\mathrm{TB}}$ phase observed for the binary mixtures of 9.9 and 17.7 mol\% CB4SCB; these emerged upon holding at a temperature in the vicinity of the $\mathrm{I}-\mathrm{N}_{\mathrm{TB}}$ phase transitions of the binary mixtures. The optical textures of the $\mathrm{N}_{\mathrm{TB}}$ phases of the binary mixtures became discernible upon increasing the mol\% of CB4SCB (or decreasing the mol\% of CB2SCB) [see Fig. 8(b)-(d)]. As shown in Fig. 8(a), the $T_{\mathrm{IN}}, T_{\mathrm{NNTB}}$, and $\mathrm{N}$ phase temperature ranges of the binary mixtures gradually decreased with a decrease in the mol\% of CB4SCB (or an increase in the mol\% of CB2SCB). Eventually, the $\mathrm{N}$ phase of the binary mixture disappeared at low CB4SCB contents of $\sim 20 \mathrm{~mol} \%$. The $\mathrm{I}-\mathrm{N}_{\mathrm{TB}}$ phase-transition temperature for each binary mixture is abbreviated to $T_{\mathrm{INTB}}$, as is the I-to-mesophase phase-transition temperature of CB2SCB [Fig. 8(a)]. Interestingly, the $T_{\mathrm{NNTB}}$ and $T_{\mathrm{INTB}}$ values of the binary mixtures were continuously connected from the $T_{\mathrm{NNTB}}$ of $\mathrm{CB} 4 \mathrm{SCB}$ alone $\left(\sim 70{ }^{\circ} \mathrm{C}\right)$ to the I-to-mesophase phase-transition temperature (treated as the $T_{\mathrm{INTB}}$ ) of CB2SCB $\left(\sim 43{ }^{\circ} \mathrm{C}\right)$. As shown in Fig. $8(\mathrm{e})$, in addition, a striped texture was also observed for the binary mixture $(\sim 30 \mathrm{~mol} \% \mathrm{CB} 4 \mathrm{SCB})$ showing a narrow temperature range for the $\mathrm{N}$ phase above that of the $\mathrm{N}_{\mathrm{TB}}$ phase when POM was carried out using a uniaxially rubbed surface cell, although this texture could not be observed for the mesophase of CB2SCB alone. This indicates that the presence of the upper $\mathrm{N}$ phase could have a beneficial effect in helping the $\mathrm{N}_{\mathrm{TB}}$ phase align in a uniaxially rubbed cell. Through such POM observations, it was confirmed that the optical textures of the mesophases observed for all prepared binary mixtures were maintained (or supercooled) below room temperature without crystallization.

To further characterize the mesophase of CB2SCB, we conducted XRD measurements using mesophase and cold crystallization samples of CB2SCB. The mesophase and cold crystallization samples were prepared by rapidly cooling to $25{ }^{\circ} \mathrm{C}$ from the I phase at $140{ }^{\circ} \mathrm{C}$, and by heating from the mesophase at $25{ }^{\circ} \mathrm{C}$, respectively. The XRD measurements for both samples were conducted at $25{ }^{\circ} \mathrm{C}$. The obtained 1D XRD profiles of the mesophase and cold crystallization samples of CB2SCB at $25{ }^{\circ} \mathrm{C}$ are shown in Fig. 9. As can be seen in the figure, the diffraction peaks of the two samples are clearly different to one another. The mesophase sample formed by rapid cooling from the I phase exhibited only a broadened peak in the wide-angle region. The broadened peak centered at $2 \theta=20.8^{\circ}$ corresponds to 

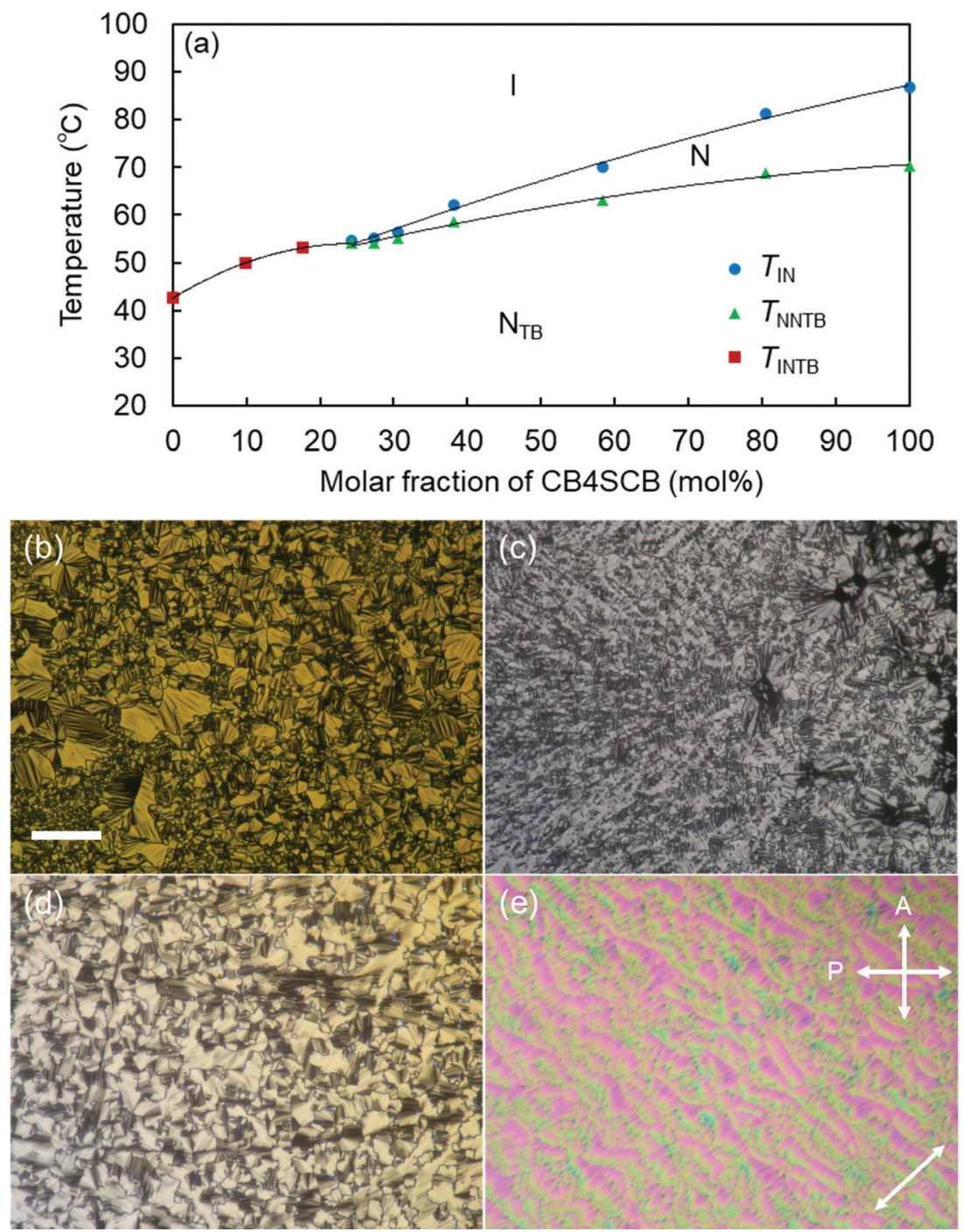

Fig. 8 (a) Phase diagram of the binary mixtures of CB2SCB and CB4SCB upon cooling as a function of the molar fraction of CB4SCB. POM images of the optical textures of the mesophases for the blends containing CB4SCB at levels of (b) 9.9 mol\% (at $20{ }^{\circ} \mathrm{C}$ ), (c) $17.7 \mathrm{~mol} \%$ (at $30{ }^{\circ} \mathrm{C}$ ), (d) $27.3 \mathrm{~mol} \%$ (at $55{ }^{\circ} \mathrm{C}$ ), and (e) $30.5 \mathrm{~mol} \%$ (at $24^{\circ} \mathrm{C}$ ). The POM observations were conducted in non-treated glass cells and uniaxially rubbed polyimide-surface glass cells with a thickness of $5 \mu \mathrm{m}$ for panels (b)-(d) and panel (e), respectively. The white scale bar in panel (b) corresponds to $50 \mu \mathrm{m}$ and the white diagonal doubleheaded arrow in panel (e) represents the rubbing direction in the sample.

approximately $4.27 \AA$, which is comparable to a lateral molecular distance observed in usual $\mathrm{N}$ phases. Additionally, no other peaks were observed in the small-angle region. These observations indicate that this state is likely a type of nonlayered mesophase with a liquid-like correlation or an $\mathrm{N}$-type nature. If this mesophase of CB2SCB has a periodic electron density modulation such as in the case of Sm phases, Bragg scattering peaks should be observed in the small-angle region. On the other hand, the cold crystallization sample was found to exhibit many sharp diffraction peaks due to the presence of a crystal structure.

With respect to the mesophase of CB2SCB, POM observations revealed modulated $\mathrm{N}$-like or pseudo-layered $\mathrm{N}_{\mathrm{TB}}$-like textures, and the XRD results indicated its non-layered and fluidic nature. In addition, DSC measurements indicated its first order phase-transition property. Furthermore, POM observations of the contact preparation and binary mixtures revealed that the mesophase of CB2SCB was miscible with the $\mathrm{N}_{\mathrm{TB}}$ phase of CB4SCB, and their blends with a high mol\% of CB2SCB showed optical textures typical of the $\mathrm{N}_{\mathrm{TB}}$ phase, which were formed directly from each I phase. It was therefore suggested that the mesophase of CB2SCB may also be the $\mathrm{N}_{\mathrm{TB}}$ phase. In other words, the $\mathrm{N}_{\mathrm{TB}}$ phase of CB2SCB directly formed from the I phase without any intermediate $\mathrm{N}$ phase, which is particularly rare. ${ }^{54,55,90}$ There have been only a few examples of single component $^{54,55}$ and mixed ${ }^{90}$ LC dimer systems that exhibited this direct $\mathrm{N}_{\mathrm{TB}}$ formation from the I phase. For example, Dawood et al. reported an imine-linked LC dimer that showed direct formation of the $\mathrm{N}_{\mathrm{TB}}$ phase from the I phase, which was observed for a dimer homolog with a short propylene $\left(\mathrm{C}_{3} \mathrm{H}_{6}\right)$ spacer, and this species was expected to possess a larger biaxiality than its longer spacer homologs. ${ }^{54,55}$ The observed $\mathrm{I}-\mathrm{N}_{\mathrm{TB}}$ phase transition indicated a strong first order property, 


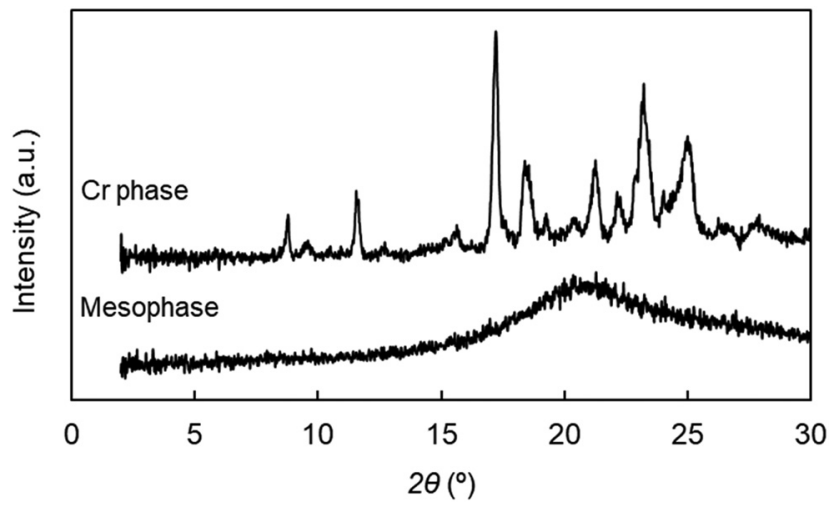

Fig. 9 1D-XRD profiles of CB2SCB for the mesophase sample at $25^{\circ} \mathrm{C}$ (bottom) and the cold crystallization sample at $25^{\circ} \mathrm{C}$ (top).

as was proposed theoretically within a restricted region of the molecular bend angles. ${ }^{91}$ As shown in Fig. 4(a) and 5, the present DSC results for the I-to-mesophase phase transition of CB2SCB also revealed a first order property. The $\Delta S / R$ at the I- $\mathrm{N}_{\mathrm{TB}}$ phase transition (abbreviated to $\Delta S_{\mathrm{INTB}} / R$ ) value of 0.55 , which was recorded at a rate of $30{ }^{\circ} \mathrm{C} \mathrm{min}{ }^{-1}$, is clearly larger than those of other $\mathrm{CB} n \mathrm{SCB}$ homologs. Such behavior is in agreement with the literature..$^{54,55,90,91}$ The previously reported $\Delta S / R$ value of 1.78 for $\mathrm{CB} 2 \mathrm{SCB}$ was smaller than the present value because it was evaluated at a rate of $10{ }^{\circ} \mathrm{C} \mathrm{min}^{-1}$, and so resulted in prior crystallization. In addition, as mentioned above, alignment of the mesophase of CB2SCB was not achieved in a uniaxially rubbed cell. This may also imply a macroscopic feature of the mesophase formed directly from the I phase, which is more similar to the Sm phase than the $\mathrm{N}$ phase. Furthermore, as shown in Fig. 8(e), the observed stripes are thin and small compared with those of typical stripes, which are similar to those observed for the ester-linked analogs exhibiting very short helical pitches. ${ }^{70}$ Further characterization of this mesophase of CB2SCB will be required together with that of the related materials.

Finally, the $T_{\mathrm{IN}}, T_{\mathrm{NNTB}}$, and $\Delta S_{\mathrm{IN}} / R$ values of all $\mathrm{CB} n \mathrm{SCB}$ homologs were compared with those of the previously reported bis(thioether)-linked CBSnSCB analogs and the ether- and thioether-linked CBOnSCB analogs (Scheme 1) with respect to individual homologs containing the same total chain length of the oligomethylene spacer and linkage atoms along the linear chain, meaning that the total chain length refers to $n+1$ for $\mathrm{CB} n \mathrm{SCB}$ and $n+2$ for CBSnSCB and CBOnSCB (Fig. 10). The specific values are listed in Table 2 , as obtained from the literature. ${ }^{61}$ In the present study, we also reinvestigated the phase transitions of $\mathrm{CBS} n \mathrm{SCB}$ and $\mathrm{CBO} n \mathrm{SCB}$ using POM, and observed that CBS11SCB and CBOnSCB ( $n=3$ and 11) also exhibited $\mathrm{N}_{\mathrm{TB}}$ formation in the small supercooled $\mathrm{N}$ domains (Fig. 11), giving $T_{\mathrm{NNTB}}$ values of $91{ }^{\circ} \mathrm{C}$ for CBS11SCB, $47{ }^{\circ} \mathrm{C}$ for $\mathrm{CBO} 3 \mathrm{SCB}$, and $92{ }^{\circ} \mathrm{C}$ for CBO11SCB. It was therefore apparent that all the reported bent $\mathrm{CBS} n \mathrm{SCB}$ and $\mathrm{CBO} n \mathrm{SCB}$ analogs (odd $n=3,5,7,9$, and 11) can form the $\mathrm{N}_{\text {Тв }}$ phase. It is interesting to note that the $T_{\mathrm{NNTB}}$ value of $47^{\circ} \mathrm{C}$ observed for CBO3SCB is significantly low compared with that of usual LC dimers $\left(\sim 80-110^{\circ} \mathrm{C}\right)$.
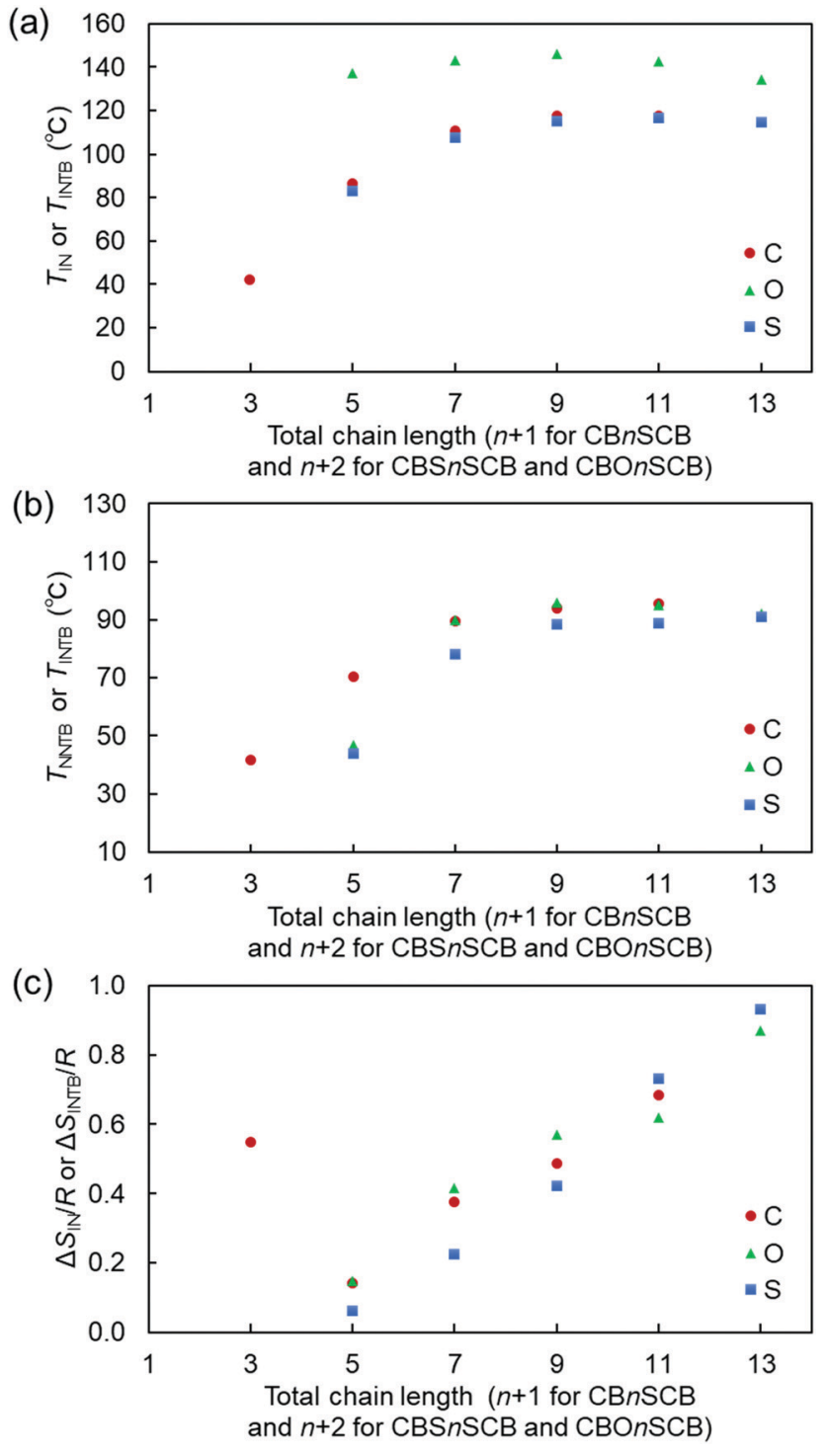

Fig. 10 (a) $T_{\text {IN }}$ (or $T_{\text {INTB }}$ for CB2SCB), (b) $T_{\text {NNTB }}$ (or $T_{\text {INTB }}$ for CB2SCB), and (c) $\Delta S_{\text {IN }} / R$ (or $\Delta S_{\text {INTB }} / R$ for $\mathrm{CB} 2 \mathrm{SCB}$ ) values of $\mathrm{CBnSCB}, \mathrm{CBSnSCB}$, and $\mathrm{CBO}$ SCB upon cooling as a function of the linkage bonds present in the structures. Here, $\mathrm{C}$ (i.e., $\mathrm{CH}_{2}$ ), $\mathrm{O}$, and $\mathrm{S}$ represent the linkage bonds of $\mathrm{CBnSCB}, \mathrm{CBSnSCB}$, and $\mathrm{CBOnSCB}$, respectively. The horizontal axes (total chain length) in panels (a)-(c) denote the total atom numbers of the linkage and the spacer along the linear chains, i.e., $n+1$ for $\mathrm{CBnSCB}$ and $n+2$ for $\mathrm{CBS} n \mathrm{SCB}$ and $\mathrm{CBO} n \mathrm{SCB}$. The phase-transition data recorded at a rate of $3{ }^{\circ} \mathrm{C} \mathrm{min}^{-1}$ for $\mathrm{CBSnSCB}$ and $\mathrm{CBOnSCB}$ were obtained from the literature. ${ }^{61}$ In addition, the present study observed $\mathrm{N}_{\text {TB }}$ phase formation for CBS11SCB, CBO3SCB, and CBO11SCB in the small supercooled $\mathrm{N}$ domains using POM, giving $T_{\text {NNTB }}$ values of $91^{\circ} \mathrm{C}$ for $\mathrm{CBS11SCB}, 47^{\circ} \mathrm{C}$ for $\mathrm{CBO} 3 \mathrm{SCB}$, and $92{ }^{\circ} \mathrm{C}$ for $\mathrm{CBO} 11 \mathrm{SCB}$.

Such low $T_{\mathrm{NNTB}}$ tendency is similar to that of another analog with a short chain CBS3SCB (see Table 2 ) $^{61}$ and a selenium-linked CBSe3SeCB analog, ${ }^{62}$ which is ascribed to the more bent geometry for shorter spacer dimers, as described later. As can be seen in Fig. 10(a), in addition to the fact that the $T_{\mathrm{IN}}$ of CBOnSCB was significantly higher than the corresponding values for $\mathrm{CB} n \mathrm{SCB}$ and $\mathrm{CBS} n \mathrm{SCB}$, the values of $\mathrm{CB} n \mathrm{SCB}$ and $\mathrm{CBS} n \mathrm{SCB}$ were similar to one another. Furthermore, the $T_{\mathrm{NNTB}}$ and $\Delta S_{\mathrm{IN}} / R$ values of 
Table 2 Phase-transition temperatures $\left(T,{ }^{\circ} \mathrm{C}\right)$ and associated entropy changes scaled by the gas constant $R(\Delta S / R)$ upon cooling at a rate of $3{ }^{\circ} \mathrm{C}$ min ${ }^{-1}$ for $\mathrm{CBSnSCB}$ and $\mathrm{CBOnSCB}(n=3,5,7,9$, and 11$)$, as quoted from the literature, ${ }^{61}$ and partially reinvestigated by POM in the present study

\begin{tabular}{|c|c|c|c|c|c|c|c|c|c|}
\hline Code & $n$ & Phase & $T\left({ }^{\circ} \mathrm{C}\right)$ & Phase & $T\left({ }^{\circ} \mathrm{C}\right)$ & Phase & $T\left({ }^{\circ} \mathrm{C}\right)$ & $\Delta S / R$ & Phase \\
\hline \multirow[t]{5}{*}{ CBSnSCB } & 3 & $\mathrm{Cr}$ & 70.1 & $\mathrm{~N}_{\mathrm{TB}}$ & $44.0^{a}$ & $\mathrm{~N}$ & 83.2 & 0.06 & I \\
\hline & 5 & $\mathrm{Cr}$ & 68.9 & $\mathrm{~N}_{\mathrm{TB}}$ & 78.0 & $\mathrm{~N}$ & 107.8 & 0.23 & I \\
\hline & 7 & G & 15.9 & $\mathrm{~N}_{\mathrm{TB}}$ & 88.3 & $\mathrm{~N}$ & 115.2 & 0.42 & I \\
\hline & 9 & $\mathrm{Cr}$ & 100.8 & $\mathrm{~N}_{\mathrm{TB}}$ & $89^{a}$ & $\mathrm{~N}$ & 116.7 & 0.73 & I \\
\hline & 11 & $\mathrm{Cr}$ & 101.4 & $\mathrm{~N}_{\mathrm{TB}}$ & $91^{a}$ & $\mathrm{~N}$ & 114.4 & 0.93 & I \\
\hline \multirow[t]{5}{*}{ CBOnSCB } & 3 & $\mathrm{Cr}$ & 101.1 & $\mathrm{~N}_{\mathrm{TB}}$ & $47^{a}$ & $\mathrm{~N}$ & 137.5 & 0.15 & I \\
\hline & 5 & $\mathrm{Cr}$ & 59.5 & $\mathrm{~N}_{\mathrm{TB}}$ & 90.1 & $\mathrm{~N}$ & 143.8 & 0.42 & I \\
\hline & 7 & G & 16.0 & $\mathrm{~N}_{\mathrm{TB}}$ & 95.9 & $\mathrm{~N}$ & 146.7 & 0.57 & I \\
\hline & 9 & $\mathrm{Cr}$ & 98.0 & $\mathrm{~N}_{\mathrm{TB}}$ & $95^{a}$ & $\mathrm{~N}$ & 143.0 & 0.62 & I \\
\hline & 11 & $\mathrm{Cr}$ & 102.5 & $\mathrm{~N}_{\mathrm{TB}}$ & $92^{a}$ & $\mathrm{~N}$ & 134.1 & 0.87 & I \\
\hline
\end{tabular}
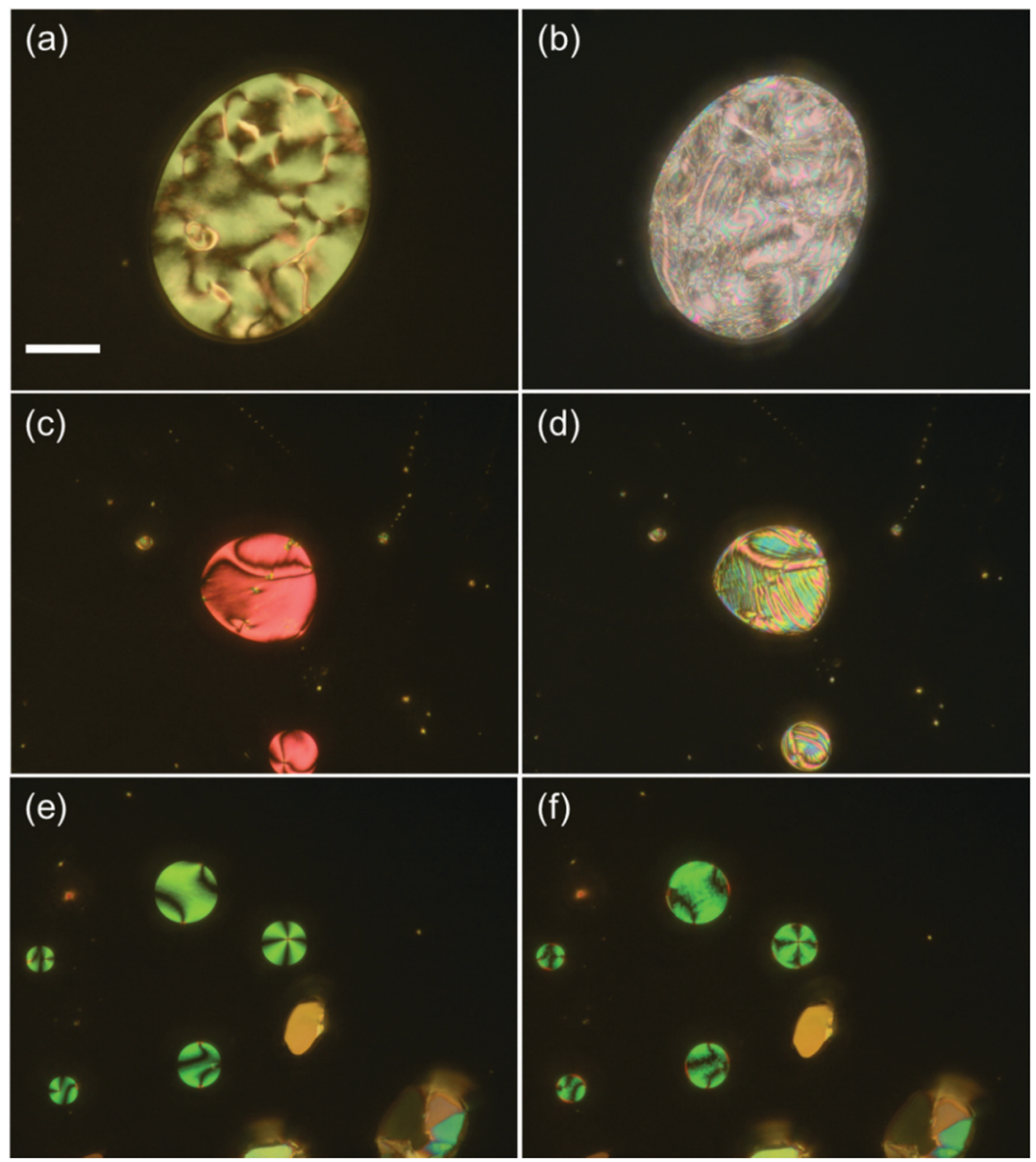

Fig. 11 POM images of the optical textures indicating the $\mathrm{N}$ to $\mathrm{N}_{\text {TB }}$ phases formed in the supercooled $\mathrm{N}$ domains: (a) the $\mathrm{N}$ phase at $96{ }^{\circ} \mathrm{C}$, and (b) the $\mathrm{N}_{\text {TB }}$ phase at $74{ }^{\circ} \mathrm{C}$ for $\mathrm{CBS11SCB}$, (c) the $\mathrm{N}$ phase at $48^{\circ} \mathrm{C}$, and (d) the $\mathrm{N}_{\text {TB }}$ phase at $33^{\circ} \mathrm{C}$ for $\mathrm{CBO} 3 \mathrm{SCB}$, and (e) the $\mathrm{N}$ phase at $93^{\circ} \mathrm{C}$, and (f) the $\mathrm{N}_{\text {TB }}$ phase at $89^{\circ} \mathrm{C}$ for $\mathrm{CBO} 11 \mathrm{SCB}$. The white scale bar in panel (a) corresponds to $50 \mu \mathrm{m}$.

CBSnSCB are lower than those of CBnSCB and CBOnSCB in the small and middle values of $n$, as shown in Fig. 10. These trends are in good agreement with those observed for other rod-like mesogens with alkyl, alkoxy, and alkylthio groups. ${ }^{93-96}$ These could be ascribed to the steric hindrance associated with the bond angles and rotation barriers of the methylene $\mathrm{C}-\mathrm{CH}_{2}-\mathrm{C}$, the ether $\mathrm{C}-\mathrm{O}-\mathrm{C}$, and the thioether $\mathrm{C}-\mathrm{S}-\mathrm{C}$ linkage bonds. The bond angles of the thioether $\mathrm{C}-\mathrm{S}-\mathrm{C}$, methylene $\mathrm{C}-\mathrm{C}-\mathrm{C}$, and ether $\mathrm{C}-\mathrm{O}-\mathrm{C}$ bonds are $\sim 100,110$, and $118^{\circ}$, respectively; the dimers should therefore be bent in the order of CBSnSCB $\left(107^{\circ}\right)>$ $\mathrm{CB} n \mathrm{SCB}\left(111^{\circ}\right)>\mathrm{CBO} n \mathrm{SCB}\left(126^{\circ}\right) .{ }^{61,64}$ In addition, C-O-C has a higher rotation barrier compared with that of $\mathrm{C}-\mathrm{S}-\mathrm{C} .{ }^{97}$ 
Hence, the less bent (or more straightened) CBOnSCB, which is assumed to have a lower steric hindrance or molecular biaxiality, exhibits higher $T_{\mathrm{IN}}$ and $\Delta S_{\mathrm{IN}} / R$ values compared with $\mathrm{CB} n \mathrm{SCB}$ and CBSnSCB. Meanwhile, the more bent CBSnSCB, which exhibits a higher steric hindrance or molecular biaxiality, displays lower $T_{\mathrm{IN}}, T_{\mathrm{NNTB}}$, and $\Delta S_{\mathrm{IN}} / R$ values compared with $\mathrm{CB} n \mathrm{SCB}$ and CBOnSCB. Nevertheless, the comparably similar $T_{\mathrm{IN}}$ values of $\mathrm{CB} n \mathrm{SCB}$ and $\mathrm{CBS} n \mathrm{SCB}$ could be ascribed to their molecular symmetries. The asymmetric and symmetric linkage bonds of $\mathrm{CB} n \mathrm{SCB}$ and $\mathrm{CBS} n \mathrm{SCB}$ contribute to the relative decrease and increase in the phase-transition temperature, respectively, which result in comparably similar $T_{\mathrm{IN}}$ values. It should be noted that compared to $\mathrm{CBS} n \mathrm{SCB}$ and $\mathrm{CBO} n \mathrm{SCB}$, the methylene-linked CBnSCB homologs exhibit a distinctly prominent stability in the $\mathrm{N}_{\mathrm{TB}}$ phase, and the ability to vitrify as $\mathrm{N}_{\mathrm{TB}} \mathrm{G}$. For example, $\mathrm{CB} n \mathrm{SCB}(n=4,6$, and 8$)$ exhibited a perfect $\mathrm{N}_{\mathrm{TB}} \mathrm{G}$ phase without partial crystallization. This behavior of $\mathrm{CB} n \mathrm{SCB}$ could be attributed to the following multiple effects. Firstly, the lower molecular polarizability of $\mathrm{CB} n \mathrm{SCB}$ compared to those of the thioether (CBSnSCB) and ether ( $\mathrm{CBO} n \mathrm{SCB})$ analogs should reduce the crystallization ability of the molecules. In addition, asymmetric structures can effectively contribute to prevent crystallization, resulting in formation of the $\mathrm{N}_{\mathrm{TB}} \mathrm{G}$ phase. ${ }^{67,68}$ The intermediate molecular bend $\left(111^{\circ}\right)$ of $\mathrm{CB} n \mathrm{SCB}$ may also contribute to the stability of the $\mathrm{N}_{\mathrm{TB}}$ phase, since bent molecules fill the space, forming Sm layers. ${ }^{98,99}$

\section{Conclusions}

A homologous series of cyanobiphenyl-based LC dimers linked with methylene and thioether linkages, i.e., $\mathrm{CB} n \mathrm{SCB}$, where $n=2,4,6,8$, and 10, were developed for the first time. CBnSCB homologs $(n=4,6,8$, and 10$)$ formed the $\mathrm{N}_{\mathrm{TB}}$ phase below the $\mathrm{N}$ phase upon cooling. Interestingly, the results obtained for CB2SCB implied a direct formation of the $\mathrm{N}_{\mathrm{TB}}$ phase from the I phase, which is in marked contrast to the common $\mathrm{N}_{\mathrm{TB}}-\mathrm{N}-\mathrm{I}$ phase sequence. It is noteworthy that the CBnSCB homologs ( $n=2,4,6$, and 8) exhibited $\mathrm{N}_{\mathrm{TB}}$ phases which underwent vitrification to form the $\mathrm{N}_{\mathrm{TB}} \mathrm{G}$ phase upon cooling below room temperature. In particular, $\mathrm{CB} n \mathrm{SCB}(n=6$ and 8$)$ exhibited prominent stability of the $\mathrm{N}_{\mathrm{TB}}$ and $\mathrm{N}$ phases, and did not undergo cold crystallization upon heating from the $\mathrm{N}_{\mathrm{TB}} \mathrm{G}$ phase up to the I phase. In addition, the present study reinvestigated the phase-transition behaviors of the CBSnSCB and CBOnSCB analogs $\left(n=3,5,7,9\right.$, and 11) using POM, and $\mathrm{N}_{\mathrm{TB}}$ phase formation was observed from the small supercooled $\mathrm{N}$ domains of CBS11SCB, CBO3SCB, and CBO11SCB, indicating that all reported bent $\mathrm{CBS} n \mathrm{SCB}$ and $\mathrm{CBO} n \mathrm{SCB}$ dimers $(n=3,5,7,9$, and 11) potentially exhibit the $\mathrm{N}_{\mathrm{TB}}$ phase. Overall, the $\mathrm{CB} n \mathrm{SCB}$ homologs presented remarkably stable $\mathrm{N}_{\mathrm{TB}}$ phases and vitrifiable tendencies compared with the previously reported CBSnSCB and CBOnSCB analogs. This study demonstrates a new LC homologous series exhibiting a stable $\mathrm{N}_{\mathrm{TB}}$ phase over a wide range, which can be supercooled to room temperature. Such characteristic dimers will lead to more detailed evaluations of the $\mathrm{N}_{\mathrm{TB}}$ phases, and will likely lead to the discovery of interesting structural and physical properties.

\section{Conflicts of interest}

There are no conflicts to declare.

\section{Acknowledgements}

This work was financially supported by the Japan Society for the Promotion of Science KAKENHI (grant no. $17 \mathrm{~K} 14493$ and 20K15351), the Naito Research Grant, and research grants from the Toukai Foundation for Technology and Toyohashi University of Technology. We would like to thank Prof. Masatoshi Tokita for permitting the temperature-variable XRD measurements at Tokyo Institute of Technology, and thank the Cooperative Research Facility Center at the Toyohashi University of Technology for assisting with the 1D-XRD measurements. We would also like to thank Ms Tsugumi Shiokawa and Dr Hiroko Tada in the Division of Instrumental Analysis (Okayama University) for carrying out the mass measurements.

\section{References}

1 J. W. Emsley, G. R. Luckhurst, G. N. Shilstone and I. Sage, Mol. Cryst. Liq. Cryst., 1984, 102, 223.

2 P. J. Barnes, A. G. Douglass, S. K. Heeks and G. R. Luckhurst, Liq. Cryst., 1993, 13, 603.

3 G. R. Luckhurst, Macromol. Symp., 1995, 96, 1.

4 A. Ferrarini, G. R. Luckhurst and P. L. Nordio, Mol. Phys., 1995, 85, 131.

5 C. T. Imrie and P. A. Henderson, Chem. Soc. Rev., 2007, 36, 2096.

6 J. Watanabe, H. Komura and T. Niori, Liq. Cryst., 1993, 13, 455.

7 M. Šepelj, A. Lesac, U. Baumeister, S. Diele, D. W. Bruce and Z. Hameršak, Chem. Mater., 2006, 18, 2050.

8 M. Šepelj, A. Lesac, U. Baumeister, S. Diele, H. L. Nguyen and D. W. Bruce, J. Mater. Chem., 2007, 17, 1154.

9 E. Białecka-Florjańczyk, I. Śledzińska, E. Górecka and J. Przedmojski, Liq. Cryst., 2008, 35, 401-406.

10 T. Yoshida, A. Sugimoto, A. Ikoma, T. Matsuoka, S. Kang, K. Sakajiri, J. Watanabe and M. Tokita, Liq. Cryst., 2015, 42, 463.

11 Y. Arakawa, S. Sasaki, K. Igawa, M. Tokita, G. Konishi and H. Tsuji, New J. Chem., 2020, 44, 17531.

12 R. B. Meyer, in Structural Problems in Liquid Crystal Physics, Molecular Fluids: Summer School in Theoretical Physics, les Houches lectures 1973, ed. R. Balian and G. Weil, Gordon and Breach, New York, 1976, pp. 271-343.

13 I. Dozov, Europhys. Lett., 2001, 56, 247.

14 R. Memmer, Liq. Cryst., 2002, 29, 483.

15 M. Cestari, S. Diez-Berart, D. A. Dunmur, A. Ferrarini, M. R. de La Fuente, D. J. B. Jackson, D. O. Lopez, G. R. Luckhurst, M. A. Perez-Jubindo, R. M. Richardson, 
J. Salud, B. A. Timimi and H. Zimmermann, Phys. Rev. E: Stat., Nonlinear, Soft Matter Phys., 2011, 84, 031704.

16 V. P. Panov, M. Nagaraj, J. K. Vij, Y. P. Panarin, A. Kohlmeier, M. G. Tamba, R. A. Lewis and G. H. Mehl, Phys. Rev. Lett., 2010, 105, 167801.

17 V. P. Panov, R. Balachandran, M. Nagaraj, J. K. Vij, M. G. Tamba, A. Kohlmeier and G. H. Mehl, Appl. Phys. Lett., 2011, 99, 261903.

18 C. S. P. Tripathi, P. Losada-Pérez, C. Glorieux, A. Kohlmeier, M. G. Tamba, G. H. Mehl and J. Leys, Phys. Rev. E: Stat., Nonlinear, Soft Matter Phys., 2011, 84, 041707.

19 G. Ungar, J. L. Feijoo, A. Keller, R. Yourd and V. Percec, Macromolecules, 1990, 23, 3411.

20 G. Ungar, V. Percec and M. Zuber, Macromolecules, 1992, 25, 75.

21 M. W. Schröder, S. Diele, G. Pelzl, U. Dunemann, H. Kresse and W. Weissflog, J. Mater. Chem., 2003, 13, 1877.

22 C. V. Yelamaggad, I. S. Shashikala and Q. Li, Chem. Mater., 2007, 19, 6561.

23 A. G. Vanakaras and D. J. Photinos, Soft Matter, 2016, 12, 2208.

24 L. M. Heist, E. T. Samulski, C. Welch, Z. Ahmed, G. H. Mehl, A. G. Vanakaras and D. J. Photinos, Liq. Cryst., 2020, 47, 2058.

25 E. T. Samulski, A. G. Vanakaras and D. J. Photinos, Liq. Cryst., 2020, 47, 2092.

26 I. Dozov and G. Luckhurst, Liq. Cryst., 2020, 47, 2098.

27 D. Chen, J. H. Porada, J. B. Hooper, A. Klittnick, Y. Shen, M. R. Tuchband, E. Korblova, D. Bedrov, D. M. Walba, M. A. Glaser, J. E. Maclennan and N. A. Clark, Proc. Natl. Acad. Sci. U. S. A., 2013, 110, 15931.

28 V. Borshch, Y.-K. Kim, J. Xiang, M. Gao, A. Jákli, V. P. Panov, J. K. Vij, C. T. Imrie, M. G. Tamba, G. H. Mehl and O. D. Lavrentovich, Nat. Commun., 2013, 4, 2635.

29 C. Zhu, M. R. Tuchband, A. Young, M. Shuai, A. Scarbrough, D. M. Walba, J. E. Maclennan, C. Wang, A. Hexemer and N. A. Clark, Phys. Rev. Lett., 2016, 116, 147803.

30 W. D. Stevenson, Z. Ahmed, X. B. Zeng, C. Welch, G. Ungar and G. H. Mehl, Phys. Chem. Chem. Phys., 2017, 19, 13449.

31 Y. Cao, J. Feng, A. Nallapaneni, Y. Arakawa, K. Zhao, G. H. Mehl, F. Liu and C. Zhu, arXiv:1907.11330.

32 Y. Cao, C. Feng, A. Jakli, C. Zhu and F. Liu, Giant, 2020, 2, 100018.

33 W. D. Stevenson, X. Zeng, C. Welch, A. K. Thakur, G. Ungar and G. H. Mehl, J. Mater. Chem. C, 2020, 8, 1041.

34 V. P. Panov, S. P. Sreenilayam, Y. P. Panarin, J. K. Vij, C. J. Welch and G. H. Mehl, Nano Lett., 2017, 17, 7515.

35 N. Trbojevic, D. J. Read and M. Nagaraj, Phys. Rev. E, 2019, 99, 062704.

36 J. Zhou, W. Tang, Y. Arakawa, H. Tsuji and S. Aya, Phys. Chem. Chem. Phys., 2020, 22, 9593.

37 S. P. Sreenilayam, Y. P. Panarin, J. K. Vij, V. P. Panov, A. Lehmann, M. Poppe, M. Prehm and C. Tschierske, Nat. Commun., 2016, 7, 11369.

38 S. P. Sreenilayam, Y. P. Panarin, J. K. Vij, A. Lehmann, M. Poppe and C. Tschierske, Phys. Rev. Mater., 2017, 1, 035604.

39 M. G. Tamba, S. M. Salili, C. Zhang, A. Jákli, G. H. Mehl, R. Stannarius and A. Eremin, RSC Adv., 2015, 5, 11207.
40 J. P. Abberley, R. Killah, R. Walker, J. M. D. Storey, C. T. Imrie, M. Salamończyk, C. Zhu, E. Gorecka and D. Pociecha, Nat. Commun., 2018, 9, 228.

41 M. T. Murachver, A. Nemati, M. Salamończyk, C. Bullock, Z. Sabata, H. Rahmani, T. Vorobiova, A. Izadnegahdar, S. M. Salili, V. Norman, C. Zhu, T. Hegmann, S. N. Sprunt, J. T. Gleeson and A. Jákli, Soft Matter, 2019, 15, 3283.

42 K. Merkel, A. Kocot, J. K. Vij and G. Shanker, Phys. Rev. E, 2018, 98, 022704.

43 K. Merkel, A. Kocot, G. H. Mehl and C. Welch, Phys. Chem. Chem. Phys., 2019, 21, 22839.

44 C. Meyer, C. Blanc, G. R. Luckhurst, P. Davidson and I. Dozov, Sci. Adv., 2020, 6, eabb8212.

45 A. Mertelj, L. Cmok, N. Sebastián, R. J. Mandle, R. R. Parker, A. C. Whitwood, J. W. Goodby and M. Čopič, Phys. Rev. X, 2018, 8, 041025.

46 N. Chaturvedi and R. D. Kamien, Phys. Rev. E, 2019, 100, 022704. 47 P. A. Henderson and C. T. Imrie, Liq. Cryst., 2011, 38, 1407. 48 R. J. Mandle, E. J. Davis, S. A. Lobato, C.-C. A. Vol, S. J. Cowling and J. W. Goodby, Phys. Chem. Chem. Phys., 2014, 16, 6907.

49 R. J. Mandle, E. J. Davis, C. C. A. Voll, C. T. Archbold, J. W. Goodby and S. J. Cowling, Liq. Cryst., 2015, 42, 688.

50 N. Sebastián, D. O. López, B. Robles-Hernández, M. R. de la Fuente, J. Salud, M. A. Pérez-Jubindo, D. A. Dunmur, G. R. Luckhurst and D. J. B. Jackson, Phys. Chem. Chem. Phys., 2014, 16, 21391.

51 Z. Ahmed, C. Welch and G. H. Mehl, RSC Adv., 2015, 5, 93513.

52 R. J. Mandle, C. C. A. Voll, D. J. Lewis and J. W. Goodby, Liq. Cryst., 2016, 43, 13.

53 R. J. Mandle, C. T. Archbold, J. P. Sarju, J. L. Andrews and J. W. Goodby, Sci. Rep., 2016, 6, 36682.

54 A. A. Dawood, M. C. Grossel, G. R. Luckhurst, R. M. Richardson, B. A. Timimi, N. J. Wells and Y. Z. Yousif, Liq. Cryst., 2016, 43, 2.

55 A. A. Dawood, M. C. Grossel, G. R. Luckhurst, R. M. Richardson, B. A. Timimi, N. J. Wells and Y. Z. Yousif, Liq. Cryst., 2017, 44, 106.

56 T. Ivšić, U. Baumeister, I. Dokli, A. Mikleušević and A. Lesac, Liq. Cryst., 2017, 44, 93.

57 D. A. Paterson, J. P. Abberley, W. T. A. Harrison, J. M. D. Storey and C. T. Imrie, Liq. Cryst., 2017, 44, 127.

58 A. Lesac, U. Baumeister, I. Dokli, Z. Hameršak, T. Ivšić, D. Kontrec, M. Viskić, A. Knežević and R. J. Mandle, Liq. Cryst., 2018, 45, 1101.

59 A. Knežević, M. Sapunar, A. Buljan, I. Dokli, Z. Hameršak, D. Kontrec and A. Lesac, Soft Matter, 2018, 14, 8466.

60 K. Watanabe, T. Tamura, S. Kang and M. Tokita, Liq. Cryst., 2018, 45, 924.

61 Y. Arakawa, K. Komatsu and H. Tsuji, New J. Chem., 2019, 43, 6786.

62 Y. Arakawa and H. Tsuji, J. Mol. Liq., 2019, 289, 111097.

63 E. Cruickshank, M. Salamończyk, D. Pociecha, G. J. Strachan, J. M. D. Storey, C. Wang, J. Feng, C. Zhu, E. Gorecka and C. T. Imrie, Liq. Cryst., 2019, 46, 1595. 
64 Y. Arakawa, K. Komatsu, S. Inui and H. Tsuji, J. Mol. Struct., 2020, 1199, 126913.

65 R. J. Mandle and J. W. Goodby, Chem. - Eur. J., 2019, 25, 14454.

66 A. Zep, K. Pruszkowska, Ł. Dobrzycki, K. Sektas, P. Szałański, P. H. Marek, M. K. Cyrański and R. R. Sicinski, CrystEngComm, 2019, 21, 2779.

67 Y. Arakawa, Y. Ishida and H. Tsuji, Chem. - Eur. J., 2020, 26, 3767.

68 Y. Arakawa, K. Komatsu, Y. Ishida and H. Tsuji, Liq. Cryst., 2020, DOI: 10.1080/02678292.2020.1800848.

69 A. Knežević, I. Dokli, J. Novak, D. Kontrec and A. Lesac, Liq. Cryst., 2020, DOI: 10.1080/02678292.2020.1817585.

70 Y. Arakawa, K. Komatsu, J. Feng, C. Zhu and H. Tsuji, Mater. Adv., 2021, 2, 261.

71 Y. Arakawa, K. Komatsu, Y. Ishida, K. Igawa and H. Tsuji, Tetrahedron, 2021, 81, 131870.

72 R. Walker, M. Majewska, D. Pociecha, A. Makal, J. M. D. Storey, E. Gorecka and C. T. Imrie, ChemPhysChem, 2021, DOI: 10.1002/cphc.202000993.

73 Y. Wang, G. Singh, D. M. Agra-Kooijman, M. Gao, H. K. Bisoyi, C. Xue, M. R. Fisch, S. Kumar and Q. Li, CrystEngComm, 2015, 17, 2778.

74 S. M. Jansze, A. Martínez-Felipe, J. M. D. Storey, A. T. M. Marcelis and C. T. Imrie, Angew. Chem., Int. Ed., 2015, 54, 643.

75 R. J. Mandle and J. W. Goodby, ChemPhysChem, 2016, 17, 967.

76 A. Al-Janabi, R. J. Mandle and J. Goodby, RSC Adv., 2017, 7, 47235.

77 R. J. Mandle and J. W. Goodby, Angew. Chem., Int. Ed., 2018, 57, 7096.

78 W. D. Stevenson, J. An, X. B. Zeng, M. Xue, H. X. Zou, Y. S. Liu and G. Ungar, Soft Matter, 2018, 14, 3003.

79 D. Chen, M. Nakata, R. Shao, M. R. Tuchband, M. Shuai, U. Baumeister, W. Weissflog, D. M. Walba, M. A. Glaser, J. E. Maclennan and N. A. Clark, Phys. Rev. E: Stat., Nonlinear, Soft Matter Phys., 2014, 89, 022506.

80 P. Sreenilayam, V. P. Panov, J. K. Vij and G. Shanker, Liq. Cryst., 2017, 44, 244.

81 J. Xiang, A. Varanytsia, F. Minkowski, D. A. Paterson, J. M. D. Storey, C. T. Imrie, O. D. Lavrentovich and P. Palffy-Muhoray, Electrically tunable laser based on oblique heliconical cholesteric liquid crystal, Proc. Natl. Acad. Sci. U. S. A., 2016, 113, 12925.

82 Y. Wang, Z. Zheng, H. K. Bisoyi, K. G. Gutierrez-Cuevas, L. Wang, R. S. Zola and Q. Li, Mater. Horiz., 2016, 3, 442.

83 M. Mrukiewicz, O. S. Iadlovska, G. Babakhanova, S. Siemianowski, S. V. Shiyanovskii and O. D. Lavrentovich, Liq. Cryst., 2019, 46, 1544.

84 S. Krishna Prasad, P. Lakshmi Madhuri, P. Satapathy and C. V. Yelamaggad, Appl. Phys. Lett., 2018, 112, 253701.

85 V. Sridurai, M. B. Kanakala, C. V. Yelamaggad and G. G. Nair, Soft Matter, 2019, 15, 9982.

86 S. Aya, P. Salamon, D. A. Paterson, J. M. D. Storey, C. T. Imrie, F. Araoka, A. Jákli and Á. Buka, Adv. Mater. Interfaces, 2019, 6, 1802032.

87 C. Feng, J. Feng, R. Saha, Y. Arakawa, J. Gleeson, S. Sprunt, C. Zhu and A. Jákli, Phys. Rev. Res., 2020, 2, 032004.

88 A. Aouini, M. Nobili, E. Chauveau, P. Dieudonné-George, G. Damême, D. Stoenescu, I. Dozov and C. Blanc, Crystals, 2020, 10, 1110.

89 Y. Arakawa, Y. Sasaki and H. Tsuji, J. Mol. Liq., 2019, 280, 153.

90 C. T. Archbold, E. J. Davis, R. J. Mandle, S. J. Cowling and J. W. Goodby, Soft Matter, 2015, 11, 7547.

91 C. Greco, G. R. Luckhurst and A. Ferrarini, Soft Matter, 2014, 10, 9318.

92 R. J. Mandle, E. J. Davis, C. T. Archbold, S. J. Cowling and J. W. Goodby, J. Mater. Chem. C, 2014, 2, 556.

93 Y. Arakawa, S. Kang, H. Tsuji, J. Watanabe and G. Konishi, RSC Adv., 2016, 6, 16568.

94 Y. Arakawa and H. Tsuji, Mol. Cryst. Liq. Cryst., 2017, 647, 422.

95 D. Węgłowska, P. Kula and J. Herman, RSC Adv., 2016, $6,403$.

96 Y. Arakawa, S. Inui and H. Tsuji, Liq. Cryst., 2018, 45, 811. 97 X. D. Li, S. K. Lee, S. Kang, M. Tokita, S. Kawauchi and J. Watanabe, Chem. Lett., 2009, 38, 424.

98 T. Akutagawa, Y. Matsunaga and K. Yashuhara, Liq. Cryst., 1994, 17, 659.

99 T. Niori, T. Sekine, J. Watanabe, T. Furukawa and H. Takezoe, J. Mater. Chem., 1996, 1231. 